\title{
Systemic Copper Disorders Influence the Olfactory Function in Adult Rats: Roles of Altered Adult Neurogenesis and Neurochemical Imbalance
}

\author{
Sherleen Xue-Fu Adamson ${ }^{1,+}{ }^{,}$Wei Zheng ${ }^{1,2, *}$, Zeynep Sena Agim ${ }^{1}$, Sarah Du ${ }^{1}$, Sheila Fleming ${ }^{3}$, \\ Jonathan Shannahan ${ }^{1}$ and Jason Cannon ${ }^{1,2, *}$ \\ 1 School of Health Sciences, Purdue University, West Lafayette, IN 47907, USA; \\ sherleen.adamson@gmail.com (S.X.-F.A.); sena.agim@gmail.com (Z.S.A.); sarah.yang.du@emory.edu (S.D.); \\ jshannah@purdue.edu (J.S.) \\ 2 Purdue Institute for Integrative Neurosciences, Purdue University, West Lafayette, IN 47907, USA \\ 3 Department of Pharmaceutical Sciences, Northeast Ohio Medical University, Rootstown, OH 44272, USA; \\ sfleming1@neomed.edu \\ * Correspondence: wzheng@purdue.edu (W.Z.); cannonjr@purdue.edu (J.C.); \\ Tel.: +1-765-496-6447 (W.Z.); +1-765-494-0794 (J.C.); Fax: +1-765-496-1377 (W.Z. \& J.C.) \\ + Dr. Sherleen Xue-Fu Adamson is now a toxicology scientist at the Procter and Gamble Company, \\ Mason, OH 45040, USA.
}

\section{check for} updates

Citation: Adamson, S.X.-F.; Zheng W.; Agim, Z.S.; Du, S.; Fleming, S.; Shannahan, J.; Cannon, J. Systemic Copper Disorders Influence the Olfactory Function in Adult Rats: Roles of Altered Adult Neurogenesis and Neurochemical Imbalance. Biomolecules 2021, 11, 1315. https:// doi.org/10.3390/biom11091315

Academic Editors: Valeria M. Nurchi and Jan Aaseth

Received: 6 August 2021

Accepted: 30 August 2021

Published: 6 September 2021

Publisher's Note: MDPI stays neutral with regard to jurisdictional claims in published maps and institutional affiliations.

Copyright: (c) 2021 by the authors. Licensee MDPI, Basel, Switzerland. This article is an open access article distributed under the terms and conditions of the Creative Commons Attribution (CC BY) license (https:/ / creativecommons.org/licenses/by/ $4.0 /)$.

\begin{abstract}
Disrupted systemic copper $(\mathrm{Cu})$ homeostasis underlies neurodegenerative diseases with early symptoms including olfactory dysfunction. This study investigated the impact of Cu dyshomeostasis on olfactory function, adult neurogenesis, and neurochemical balance. Models of Cu deficiency $(\mathrm{CuD})$ and $\mathrm{Cu}$ overload $(\mathrm{CuO})$ were established by feeding adult rats with $\mathrm{Cu}$-restricted diets plus ip. injection of a $\mathrm{Cu}$ chelator (ammonium tetrathiomolybdate) and excess $\mathrm{Cu}$, respectively. $\mathrm{CuD}$ reduced $\mathrm{Cu}$ levels in the olfactory bulb (OB), subventricular zone (SVZ), rostral migratory stream (RMS), and striatum, while $\mathrm{CuO}$ increased $\mathrm{Cu}$ levels in these areas. The buried pellet test revealed both $\mathrm{CuD}$ and $\mathrm{CuO}$ prolonged the latency to uncover food. $\mathrm{CuD}$ increased neural proliferation and stem cells in the SVZ and newly differentiated neurons in the OB, whereas $\mathrm{CuO}$ caused opposite alterations, suggesting a "switch"-type function of $\mathrm{Cu}$ in regulating adult neurogenesis. $\mathrm{CuO}$ increased GABA in the $\mathrm{OB}$, while both $\mathrm{CuD}$ and $\mathrm{CuO}$ reduced DOPAC, HVA, 5-HT and the DA turnover rate in olfactory-associated brain regions. Altered mRNA expression of $\mathrm{Cu}$ transport and storage proteins in tested brain areas were observed under both conditions. Together, results support an association between systemic $\mathrm{Cu}$ dyshomeostasis and olfactory dysfunction. Specifically, altered adult neurogenesis along the SVZ-RMS-OB pathway and neurochemical imbalance could be the factors that may contribute to olfactory dysfunction.
\end{abstract}

Keywords: $\mathrm{Cu}$ deficiency; $\mathrm{Cu}$ overload; olfactory; subventricular zone; rostral migratory stream; neurochemical homeostasis; adult neurogenesis; GABA

\section{Introduction}

Copper $(\mathrm{Cu})$ is an essential element for human health serving as an indispensable cofactor for numerous enzymes and proteins that are widely involved in a number of diverse biochemical reactions [1-4]. In the central nervous system (CNS), $\mathrm{Cu}$-containing enzymes such as cytochrome $C$ oxidase, superoxide dismutase, dopamine- $\beta$-monooxygenase, and tyrosinase, play pivotal roles in various biological processes, such as energy metabolism, iron metabolism, anti-oxidative defense, and synthesis of neurotransmitters and neuropeptides, among others [5-8]. Nevertheless, by actively interacting with oxygen, excessive free $\mathrm{Cu}$ ions can initiate a cascade of reactions leading to the generation of highly damaging hydroxyl radicals. Thus, a dyshomeostasis of $\mathrm{Cu}$, in either the form of $\mathrm{Cu}$ deficiency $(\mathrm{CuD})$ or $\mathrm{Cu}$ overload $(\mathrm{CuO})$, is deemed disruptive to normal brain function. 
Imbalanced $\mathrm{Cu}$ homeostasis has been well characterized in two inherited neurodegenerative disorders, i.e., Menkes disease and Wilson's disease. In Menkes disease, $\mathrm{Cu}$ deficiency occurs due to ATP7A mutations while in Wilson's disease, a genetic defect in ATP7B causes excessive $\mathrm{Cu}$ accumulation in the liver and brain $[9,10]$. A large body of evidence has also implicated a disrupted $\mathrm{Cu}$ homeostasis in pathogeneses of neurodegenerative disorders, e.g., Parkinson's disease (PD), Alzheimer's disease (AD), amyotrophic lateral sclerosis, prion disease, and Huntington's disease [11-15]. Our own human studies on manganese exposure-associated Parkinsonian disorder reveal that $\mathrm{Cu}$ levels are significantly higher in blood, serum, and saliva samples from manganese-exposed smelters and welders compared to control workers [16-18]. Moreover, studies by our laboratory and others on manganese-poisoned animal models (non-human primates and rodents) demonstrate a significant increase of $\mathrm{Cu}$ in brain regions including caudate putamen, striatum, hippocampus, and choroid plexus [19-22]. Thus, $\mathrm{Cu}$ dyshomeostasis unequivocally underlies neurodegenerative diseases and disorders.

By using synchrotron X-ray fluorescent microscopy, we have reported an extraordinarily high $\mathrm{Cu}$ level in the subventricular zone (SVZ) of the rat brain [23]. Data by atomic absorption spectrophotometry further confirm significantly elevated Cu levels in the SVZ and olfactory bulb (OB) compared to other brain regions [19,24]. Importantly, the SVZ is an active proliferative niche in the adult brain. Limited data have suggested a role of $\mathrm{Cu}$ in regulating embryonic stem cell differentiation [25-27]. Given the higher levels of proliferation, migration, and differentiation occurring in the SVZ, it seems likely that the high $\mathrm{Cu}$ environment may be required to maintain normal energy metabolism and / or other biochemical reactions deemed to be essential to adult neurogenesis. However, there is a clear lack of knowledge on the role and mechanisms of $\mathrm{Cu}$ in regulating adult neurogenesis in the SVZ and OB.

During adult neurogenesis, new neurons are generated from two proliferative niches in adult brain, i.e., the SVZ in the lateral ventricles and the subgranular zone (SGZ) in the hippocampus. The SVZ is rich in neural stem/progenitor cells (NSPCs) and functions as the origin of adult neurogenesis [28,29]. The SVZ possesses 4 cell types: (i) ependymal cells facing the cerebrospinal fluid (CSF), which is secreted and regulated by the choroid plexus in brain ventricles, (ii) $\beta$-tubulin or Doublecortin (DCX)-positive Type A migratory neuroblasts, (iii) glial fibrillary acid protein (GFAP)-positive Type B astrocytic stem cells, and (iv) Nestin-positive Type $C$ transit-amplifying cells. Newly generated NSPCs in the SVZ can migrate alongside the rostral migratory stream (RMS) to reach the OB [29,30]. On this SVZ-RMS-OB pathway, the proliferating cells further differentiate in adjacent brain regions to supply renewed neurons and to compensate for the loss of neurons in order to maintain normal brain function $[28,31]$.

Loss of neurons in selective brain regions is a pathological characteristic of numerous neurodegenerative diseases including PD. Olfactory impairments, such as deficits in odor identification, detection, and discrimination, are found in patients with PD and AD [32-36]. Olfactory deficits can trigger aberrant adult neurogenesis in the SVZ-RMS-OB system. Previous studies in zebrafish have shown that $\mathrm{Cu}$ is capable of inducing olfactory dysfunction, abnormal neurogenesis, and dysfunctional locomotor behavior [4]. Clinical evidence also suggests an olfactory dysregulation in patients with $\mathrm{Cu}$-homeostasis dysfunctions in Wilson's disease [37,38]. Thus, it has become necessary to investigate the role of $\mathrm{Cu}$ in regulating adult neurogenesis in the SVZ, which ultimately affects olfactory function.

Maintaining a balanced cellular $\mathrm{Cu}$ homeostasis requires close coordinations among a group of $\mathrm{Cu}$ regulatory proteins [6,39]. These include $\mathrm{Cu}$ transporter-1 (CTR1) and divalent metal transporter-1 (DMT1) which function to regulate $\mathrm{Cu}$ uptake by the cell membrane [40]. Further, there are various isoforms of metallothioneins regulating intracellular $\mathrm{Cu}$ storage [6]. These $\mathrm{Cu}$ regulatory proteins exist in the mammalian brain with a particular abundance in the brain capillary endothelial cells constituting the blood-brain barrier and in the choroid plexus epithelial cells forming the blood-CSF barrier [6,39,41-43]. Our recent data has confirmed the presence of these regulatory proteins in the SVZ [19]. 
Conceivably, disruption of $\mathrm{Cu}$ systemic homeostasis would adversely affect the expression of these $\mathrm{Cu}$ regulatory proteins in the $\mathrm{Cu}$-rich SVZ, which would in turn affect normal olfactory function.

The current study was designed to investigate whether alteration of systemic $\mathrm{Cu}$ levels, resulting from either $\mathrm{Cu}$ deficiency $(\mathrm{CuD})$ or $\mathrm{Cu}$ overload $(\mathrm{CuO})$ conditions, has any impact on olfactory function in adult rats through the modulation of adult neurogenesis in the $\mathrm{Cu}$-rich SVZ and $\mathrm{OB}$, and to determine the ensuring alteration of neurochemical balance within the $\mathrm{OB}$. We first established and verified animal models of $\mathrm{CuD}$ and $\mathrm{CuO}$, followed by examining alterations in olfactory function. Further, we investigated the mechanism by which $\mathrm{CuD}$ or $\mathrm{CuO}$ interrupted adult neurogenesis and neurochemical balance in brain regions critical to the olfactory function.

\section{Material and Methods}

\subsection{Materials}

Chemical reagents were purchased from the following sources: mouse monoclonal anti-BrdU antibody from Santa Cruz Biotechnology (Dallas, TX, USA), ProLong Gold antifade reagent, Alexa Fluor 488 goat anti-rabbit IgG (H+L) antibody (Catalog No. A11008) and Alexa Fluor 555 goat anti-mouse IgG $(\mathrm{H}+\mathrm{L})$ antibody (Catalog No. A21424) from Life Technologies (Carlsbad, CA, USA); anti-doublecortin (DCX) (Catalog No. ab18723) and antiNeuN (Catalog No. ab177487) antibodies, and chicken polyclonal anti-glial fibrillary acidic protein (GFAP) antibodies from Abcam (Cambridge, MA, USA); anti-tyrosine hydroxylase sheep polyclonal antibody (Catalog No. AB1542) from Millipore (Burlington, MA, USA); anti-GAD67 mouse monoclonal antibody (Catalog No. ab26116) from Abcam (Branford, CT, USA); paraformaldehyde (PFA) from ACROS Organics (Morris Plains, NJ, USA); bovine serum albumin (BSA) from AMRESCO (Solon, OH, USA); and normal goat serum and normal donkey serum from Jackson Immuno Research Labs (West Grove, PA, USA). All reagents were of analytical grade, HPLC grade, or the best available pharmaceutical grade.

\subsection{Animals and Treatment}

Male Sprague-Dawley rats were purchased from Taconic Biosciences (Hudson, NY, USA). At the time of use, the rats were 10-weeks old weighing 220-250 g. Upon arrival, rats were housed in a temperature-controlled, 12/12-h light/dark cycle room and allowed to acclimate for one week prior to experimentation. Rats were provided with deionized water and designated pellet (See details in systemic Cu-deficiency/overload treatments) ad libitum. The study was conducted in compliance with standard animal use practices and approved by the Animal Care and Use Committee of Purdue University (Protocol\#1112000526 approved on 17 May 2019).

The methods to create systemic $\mathrm{Cu}$ deficiency $(\mathrm{CuD})$ and $\mathrm{Cu}$ overload $(\mathrm{CuO})$ rat models have been extensively published in literature [44-52]. In addition to $\mathrm{Cu}$-controlled diet, the $\mathrm{CuD}$ and $\mathrm{CuO}$ models require ip. injections of a $\mathrm{Cu}$ chelator or $\mathrm{Cu}$ supplement, respectively. Thus, we modified existing approaches and designed the protocol as illustrated in Figure 1A. Briefly, after a 1-week acclimation period, rats were randomly assigned to control, $\mathrm{CuD}$, or $\mathrm{CuO}$ groups. $\mathrm{CuD}$ rats had free access to a modified AIN-93G purified $\mathrm{CuD}$ diet containing $0.3 \mathrm{ppm} \mathrm{Cu}$ (Teklad Diets from Envigo Corp, Indianapolis, IN, USA); CuD rats also received ip. injections of $10 \mathrm{mg} / \mathrm{kg}$ of the $\mathrm{Cu}$ chelator ammonium tetrathiomolybdate (TTM) once daily for 7 days a week. $\mathrm{CuO}$ rats had free access to a normal AIN-93G purified $\mathrm{CuO}$ diet containing 6 ppm $\mathrm{Cu}$ (Teklad Diets from Envigo Corp, Indianapolis, IN, USA); these rats also received ip. injections of $3 \mathrm{mg} \mathrm{Cu} / \mathrm{kg}$ as $\mathrm{CuCl}_{2}$ once daily for 7 days a week. Control rats had free access to the normal AIN-93G purified diet and received daily ip. injections of saline. All treatments lasted for 2 consecutive weeks. $\mathrm{Cu}$ concentrations in serum, plasma, and cerebrospinal fluid (CSF) of treated animals were determined by atomic absorption spectrophotometry (AAS) to verify the effectiveness of $\mathrm{CuD}$ and $\mathrm{CuO}$ treatments. 
(A)

Treatments ( $\mathbf{7}$ days/week for $\mathbf{2}$ weeks):

- Ct: i.p. Saline + AIN-93G diet

- CuD: i.p. 10 mg/kg TTM + AIN-93G CuD diet

$100 \mathrm{mg} / \mathrm{kg} \mathrm{BrdU}$,

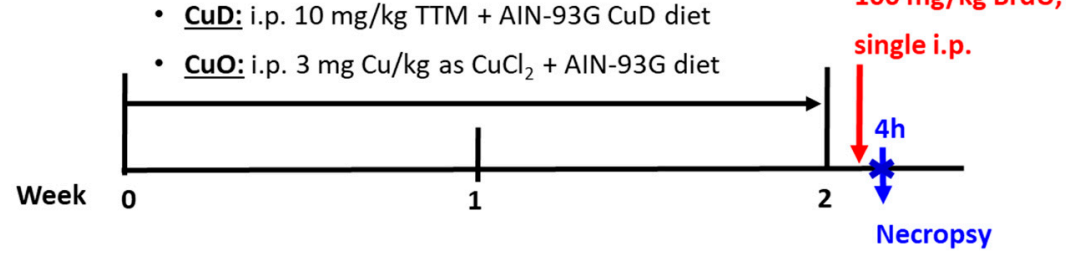

SVZ Proliferation

(BrdU/DAPI)

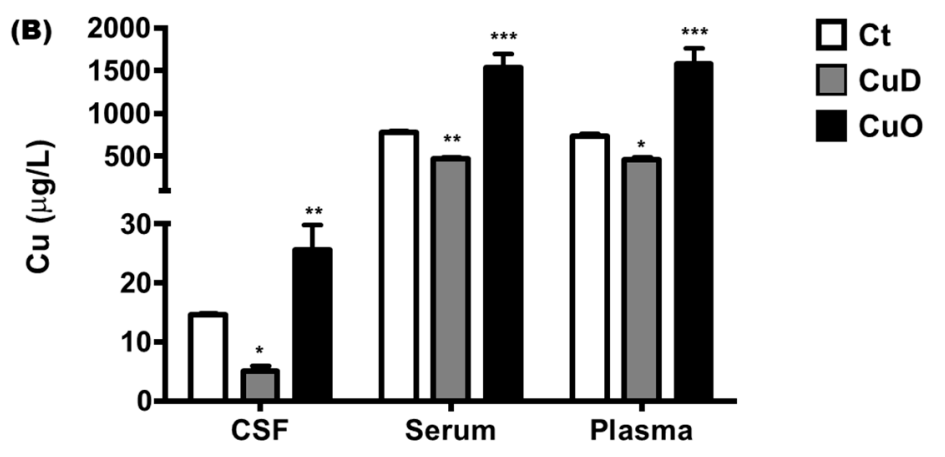

Figure 1. Experimental design and model verification. (A). Protocol for 2-week $\mathrm{CuD}$ or $\mathrm{CuO}$ treatments in rats. $\mathrm{Ct}$ : control; $\mathrm{CuD}$ : $\mathrm{Cu}$ deficiency; $\mathrm{CuO}$ : $\mathrm{Cu}$ overload. (B). Cu concentrations in body fluids. CSF: cerebrospinal fluid. Data represents mean \pm SEM, $\mathrm{n}=6-7 /$ group. ${ }^{*}: p<0.05,{ }^{* *}: p<0.01$, ***: $p<0.001$, as compared to the correspondent Ct group, using one-way ANOVA analysis.

To evaluate the impact of systemic $\mathrm{Cu}$ dyshomeostasis on cell proliferation in the SVZ described in Section 2.5, at $24 \mathrm{~h}$ after the last treatment, rats received a single dose of BrdU (100 mg/kg, ip.) and were necropsied $4 \mathrm{~h}$ later (Figure 1).

\subsection{Buried Pellet Test}

Olfactory function was evaluated via the buried pellet test which is based on the time taken to uncover a buried food pellet hidden under the bedding, as described in literature [53-55]. In brief, $24 \mathrm{~h}$ after the last treatment, rats were placed in a clean cage (48-cm length $\times 25$-cm width $\times 20$-cm height) and provided with several pieces of the pellets (mini marshmallows) for three consecutive days with food restriction to 85-90\% of body weight. Rats were then fasted overnight before the test and habituated to the testing room for $1 \mathrm{~h}$ with no water bottle and feeder bin but with a filter top lid.

Two clean cages for testing the olfactory function were prepared in the same means with clean bedding at approximately a depth of $5 \mathrm{~cm}$ which was evenly distributed through the cage, except that one mini marshmallow was placed $3.8 \mathrm{~cm}$ below the bedding in the test cage. The test began by placing the test rat in the clean cage without marshmallow. Following $1 \mathrm{~h}$ of habituation, the test rat was removed from the clean cage, placed in the center of the test cage, and the timer was started. The latency to uncover the mini marshmallow was recorded. If the rat did not find the pellet within $5 \mathrm{~min}$, the trial was ended and a score of $300 \mathrm{~s}$ was noted. The bedding was emptied from the test cage that was then cleaned with cleaning solution and filled with clean bedding for the next trial.

\subsection{Brain Tissue Collection}

All animals were anesthetized using ketamine/xylazine $(75: 10 \mathrm{mg} / \mathrm{kg}, 1 \mathrm{mg} / \mathrm{kg}$ ip.). Blood and CSF samples were collected, followed by brain dissection. Brains were removed from the skull, one hemisphere was fixed by $4 \%$ paraformaldehyde (PFA) in phosphate-buffered saline (PBS) for 7 days and subjected to immunohistochemistry studies. 
The other hemisphere was dissected to harvest brain regions including the olfactory bulb (OB), lateral olfactory tract (LOT) also known as anterior rostral migratory stream (aRMS), subventricular zone (SVZ), choroid plexus (CP), striatum (STR), hippocampus $(\mathrm{HP})$, frontal cortex (FC), and cerebellum (CB). The harvested brain samples were stored at $-80{ }^{\circ} \mathrm{C}$ freezer for AAS, qPCR and HPLC analyses.

\subsection{Determination of $\mathrm{Cu}$ Concentration by Atomic Absorption Spectroscopy (AAS)}

Prior to AAS quantification of $\mathrm{Cu}$ levels, brain samples were digested with concentrated ultrapure $\mathrm{HNO}_{3}$ in a MARSXpress microwave-accelerated reaction system. Samples of SVZ, choroid plexus, CSF, and plasma were digested overnight with $\mathrm{HNO}_{3}$ in the oven at $55^{\circ} \mathrm{C}$. An Agilent Technologies 200 Series SpectrAA with a GTA 120 graphite tube atomizer was used to quantify $\mathrm{Cu}$ concentrations. Digested samples were diluted by 50, 500, or 1000 times with $0.1 \%(v / v) \mathrm{HNO}_{3}$ in order to maintain a reading within the concentration range of the $\mathrm{Cu}$ standard curve. The Copper AAS Standard (1000 mg/L in 5\% nitric acid) was purchased from Agilent Technologies (Part \#5190-8279). The calibration standard range for $\mathrm{Cu}$ was $0-25 \mu \mathrm{g} / \mathrm{L}$ and the detection limit for $\mathrm{Cu}$ was $0.9 \mathrm{ng} / \mathrm{mL}$ of the assay solution. Intra-day precision of the method for $\mathrm{Cu}$ was $1.6 \%$ and inter-day precision was $3.7 \%[19,24,41,56]$.

\subsection{Immunohistochemistry (IHC) Staining}

Following the fixation with $4 \%$ PFA for 7 days, brain hemispheres were dehydrated in $30 \%$ sucrose for another 7 days. Serial 30- $\mu \mathrm{m}$ thick coronal or sagittal sections were cut using a microtome and stored in cryoprotectant solution at $-20{ }^{\circ} \mathrm{C}$. Specifically, for coronal and sagittal sectioning, the brains were sectioned roughly from Bregma $2.0 \mathrm{~mm}$ to $-6.0 \mathrm{~mm}$ (coronal) and Lateral $0.2 \mathrm{~mm}$ to $4.0 \mathrm{~mm} /$ hemisphere (sagittal) according to the rat brain atlas in order to cover the entire distance of the SVZ, which yielded about 250-270 sections/brain (coronal) and 125-135 sections/hemisphere (sagittal). All of the coronal sections were placed in a twelve-well plate in serial order, and all of the sagittal sections collected from one hemisphere were placed in 6 wells of the twelve-well plate in serial order. Each well contained about 18-22 sections for both coronal and sagittal sections, which accounted for 1/12 of the total brain sections. The 18-22 sections within the same well and with the same well number order across all animals were then processed for immunohistochemistry (IHC) staining.

Every twelfth section (360 $\mu \mathrm{m}$ interval), covering the distance of the lateral ventricle and OB, was processed for IHC analysis. Sections were incubated with various primary antibodies against GAD67 (1:5000), tyrosine hydroxylase (TH) (1:500), anti-doublecortin (DCX) (1:1000), Nestin (1:500), or NeuN (1:2000) overnight at $4{ }^{\circ} \mathrm{C}$. Free-floating sections were washed with PBS $(3 \times 10 \mathrm{~min} /$ wash), incubated in $2 \mathrm{~N} \mathrm{HCl}$ for $2 \mathrm{~h}$ at room temperature, and then blocked in $0.1 \mathrm{M}$ borate buffer for $15 \mathrm{~min}$ ( $\mathrm{pH} 8.4$ ). After 3 washes with PBS (10 $\mathrm{min} /$ wash), sections were incubated in blocking solution (0.3\% Triton X-100, $1 \%$ BSA, and 5\% normal goat serum in PBS) for $1.5 \mathrm{hr}$ at room temperature, followed by overnight incubation with mouse anti-BrdU (1:500) at $4{ }^{\circ} \mathrm{C}$. The sections were washed with PBS $(3 \times 10 \mathrm{~min})$ and incubated with Alexa Fluor 555 goat anti-mouse IgG $(\mathrm{H}+\mathrm{L})$ antibody (1:500) for $2 \mathrm{~h}$ at room temperature. For imaging, sections were further incubated with DAPI (4',6-diamidino-2-phenylindole) in secondary antibody solution for $15 \mathrm{~min}$ at room temperature. All sections were then rinsed with PBS $(3 \times 10 \mathrm{~min})$ and mounted using Fluorescent Mount G.

\subsection{Confocal Imaging and Cell Counting}

After IHC processing, brain sections were examined using a Nikon TE2000-U inverted microscope equipped with a Nikon A1 confocal system from Nikon Instruments Inc. (Melville, NY, USA). Images were taken using the software NIS Elements AR (v4.20). All images were assembled and labeled in Photoshop CC. For cell counting, all sections were analyzed with appropriate filter or laser combinations under an objective lens of $20 \times / 0.75$ 
(DIC N2, $\infty 0.17$ WD). Large image plus Z-Stack scanning was employed to confine the entire SVZ from coronal.

IHC was performed simultaneously on sections from different groups to detect the target cells. Series of every twelfth section (30 $\mu \mathrm{m}$ thickness, $360 \mu \mathrm{m}$ apart) through each lateral ventricle were processed. The cell density was determined through a blinded quantitative histological analysis. A profile count method was used; every single BrdU(+) cell including partial of BrdU(+) nuclei at the border of section, or BrdU and DAPI doublelabeled cells in the different sub-region of HDG in the multiplanes throughout the entire $30 \mu \mathrm{m}$ section, were counted under the fluorescent or confocal microscope using the large Z-stacking images through a whole series of sections. Those BrdU/DAPI labeled cells were considered the target cells for cell counting. The total number of quantified cells was justified by correction $[57,58]$. The total number of BrdU/DAPI labeled cells were then calculated by the following equation:

Total cell number $=$ the sum of actual cell counting number $\times 12$ and expressed as total number/target region/brain ( $n=3$ or 4 brains for each group).

\subsection{High-Performance Liquid Chromatography (HPLC)}

Neurochemical analysis was performed similarly to described in previous studies $[59,60]$. Briefly, frozen brain samples were sonicated in $0.5 \mathrm{~mL}$ of $0.4 \mathrm{~N}$ perchloric acid $\left(\mathrm{HClO}_{4}\right)$ on ice. Samples were then centrifuged at $16,400 \times g$ for $35 \mathrm{~min}$ at $4{ }^{\circ} \mathrm{C}$. The supernatant was transferred to a $0.22 \mathrm{~mm}$ Spin-X tube with nylon filter (Corning, Corning, NY, USA) and centrifuged at $1000 \times g$ for $15 \mathrm{~min}$ at $4{ }^{\circ} \mathrm{C}$. Samples were then stored at $-80{ }^{\circ} \mathrm{C}$ until HPLC analysis.

The HPLC system consisted of a Dionex Ultimate 3000 Model ISO-31000BM pump, a model WPS-3000TBSL autosampler, Coulochem III electrochemical detector and an ESA Coulochem data station (ThermoScientific, Waltham, MA, USA) was used to measure neurotransmitter levels including GABA, glutamate, dopamine (DA), 3,4-Dihydroxyphenylacetic acid (DOPAC), homovanillic acid (HVA), serotonin (5-HT), 5-hydroxyindoleacetic acid (5-HIAA), and norepinephrine (NE) in the brain tissues of SVZ, STR, HP, and OB.

Neurochemicals were separated on a Waters XBridge reverse-phase G18 column $(150 \times 3.0 \mathrm{~mm}, 3.5 \mu \mathrm{m}$ particle size) (Water Corp, Milford, MA, USA). For monoamine separation, the mobile phase was: $80 \mathrm{mM} \mathrm{NaH}_{2} \mathrm{PO}_{4}, 10 \%$ methanol, $2 \mathrm{mM}$ octanesulfonic acid, $0.025 \mathrm{mM}$ ethylenediaminetetraacetic acid and $0.2 \mathrm{mM}$ trimethylamine, at $\mathrm{pH} 2.4$. Monoamines were detected by analytical cell set at $\mathrm{E} 1=-150 \mathrm{mV}$ and $\mathrm{E} 2=+350 \mathrm{mV}$. For quantification of GABA and glutamate, the mobile phase was $0.1 \mathrm{M} \mathrm{Na}_{2} \mathrm{HPO}_{4}, 22 \%$ methanol and $4 \%$ acetonitrile, at $\mathrm{pH}$ 6.75. Quantification of amino acid neurotransmitters was accomplished through derivatization. The samples were mixed with a derivatization agent containing 0.M o-phthaladehyde (OPA), 0.05\% 2-mercaptoethanol, $10 \%$ methanol in OPA diluent, prior to separation. Neurotransmitters in the sample were detected by analytical cell set at E1 $=-150 \mathrm{mV}$ and E2 $=+550 \mathrm{mV}$. Levels of neurotransmitters tested here were calculated using area under the curve by comparison with standard curve. Levels were normalized to total protein amount and expressed as ng neurotransmitter $/ \mathrm{mg}$ protein. DA and 5-HT turnover rates were also calculated.

\subsection{Quantitative Real-Time RT-PCR}

The transcription levels of mRNA encoding Ctr1, Dmt1, Mt1a, Mt2a, Mt3, Gfap, Nestin, $D c x, N e u N$, Th, and Gad67 were quantified using qPCR. The forward and reverse primers for all selected target genes and reference gene were designed using Primer Express 3.0 software. The sequences for all primers are listed in Table 1. All primers were obtained from Integrated DNA Technologies Ltd. (Coralville, IA, USA). Total RNA was isolated from control, $\mathrm{Cu}$-deficient and $\mathrm{Cu}$-overload rat $\mathrm{CP}, \mathrm{SVZ}$, and $\mathrm{OB}$ tissues by using TRIzol reagent following the manufacturer's directions. An aliquot of RNA $(1 \mu \mathrm{g})$ was reversetranscribed into cDNA using the BioRad iScript cDNA synthesis kit. The iTaq Universal SYBR Green Supermix was used for qPCR analyses. The amplification was run in the CFX 
Connect Real-Time PCR Detection System with an initial 3 min denaturation at $95{ }^{\circ} \mathrm{C}$, the amplification program was followed by 40 cycles of $30 \mathrm{~s}$ denaturation at $95^{\circ} \mathrm{C}, 10 \mathrm{~s}$ at $60{ }^{\circ} \mathrm{C}$ and $30 \mathrm{~s}$ extension at $72{ }^{\circ} \mathrm{C}$. A dissociation curve was used to verify that the majority of fluorescence detected could be attributed to the labeling of specific PCR products, and to verify the absence of primer dimers and sample contamination. Each qPCR reaction was run in triplicate.

Table 1. The forward and reverse primer sequences of target genes.

\begin{tabular}{|c|c|c|}
\hline Category & Gene & Primer Sequence \\
\hline Reference Gene & $A c t b$ & $\begin{array}{l}\text { Forward: 5'-AGCCATGTACGTAGCCATCC-3' } \\
\text { Reverse: 5'-CTCTCAGCTGTGGTGGTGAA-3' }\end{array}$ \\
\hline \multirow{2}{*}{$\mathrm{Cu}$ Transporter } & Ctr1 & $\begin{array}{l}\text { Forward: 5'-TCGGCCTCACACTCCCACGA-3' } \\
\text { Reverse: 5'-CGAAGCAGACCCTCTCGGGC-3' }\end{array}$ \\
\hline & Dmt1 & $\begin{array}{l}\text { Forward: 5'-TCGCAGGCGGCATCTTGGTC-3' } \\
\text { Reverse: 5'-TACCGAGCGCCCACAGTCCA-3' }\end{array}$ \\
\hline \multirow{3}{*}{$\mathrm{Cu}$ Binding Proteins } & $M t 1 a$ & $\begin{array}{l}\text { Forward: 5'-GCCTTCTTGTCGCTTACACC-3' } \\
\text { Reverse: 5'-AGGAGCAGCAGCTCTTCTTG-3' }\end{array}$ \\
\hline & $M t 2 a$ & $\begin{array}{l}\text { Forward: 5'-ACAGATGGATCCTGCTCCTG-3' } \\
\text { Reverse: 5'-GAGAACCGGTCAGGGTTGTA-3' }\end{array}$ \\
\hline & $M+3$ & $\begin{array}{l}\text { Forward: 5'-CCCTGCAGGATGTGAGAAGT-3' } \\
\text { Reverse: 5'-TTTGCTGTGCATGGGATTTA-3' }\end{array}$ \\
\hline \multirow{6}{*}{ Neuronal Markers } & Gfap & $\begin{array}{l}\text { Forward: 5'-TAGCATAAGTGGAGAGGGAA-3' } \\
\text { Reverse: } 5^{\prime} \text {-GGATTCAGAGCCAAGTGTAA-3' }\end{array}$ \\
\hline & Nestin & $\begin{array}{l}\text { Forward: 5'-ATGAGGGGCAAATCTGGGAA-3' } \\
\text { Reverse: 5'-CCAGGTGGCCTTCTGTAGAA-3' }\end{array}$ \\
\hline & $D c x$ & $\begin{array}{l}\text { Forward: 5'-ACTGAATGCTTAGGGGCCTT-3' } \\
\text { Reverse: 5'-CTGACTTGCCACTCTCCTGA-3' }\end{array}$ \\
\hline & $\operatorname{NeuN}$ & $\begin{array}{l}\text { Forward: 5'-TTCCCACCACTCTCTTGTCC-3' } \\
\text { Reverse: 5'-GCAGCCGCATAGACTCTACC-3' }\end{array}$ \\
\hline & $T h$ & $\begin{array}{l}\text { Forward: 5'-CAGGGCTGCTGTCTTCCTAC-3' } \\
\text { Reverse: 5'-GGGCTGTCCAGTACGTCAAT-3' }\end{array}$ \\
\hline & Gad67 & $\begin{array}{l}\text { Forward: } 5^{\prime} \text {-CACAAACTCAGCGGCATAGA-3' } \\
\text { Reverse: } 5^{\prime} \text {-CTGGAAGAGGTAGCCTGCAC-3' }\end{array}$ \\
\hline
\end{tabular}

Note: The PCR primer efficiencies for listed primers were between $90 \%$ and $97 \%$.

The relative mRNA expression ratios between groups were calculated using the deltadelta cycle time formulation. After confirming that the reference gene was not changed, the cycle time values of interested genes were normalized with that of the reference gene in the same sample, and then the relative ratio between control and treatment groups was calculated and expressed as relative increases by setting the control as $100 \%$. The amplification efficiencies of target genes and the internal reference were examined by determining the variations of the cycle time with a series of control template dilutions. Experimental conditions were optimized for annealing temperature, primer specificity, and amplification efficiency.

\subsection{Statistical Analysis}

All data are presented as mean \pm SEM. Statistical analyses of the differences among control, $\mathrm{CuD}$, and $\mathrm{CuO}$ groups were carried out by one-way ANOVA with a Tukey's post hoc test. Since behavioral data were not normally distributed, this set of data was analyzed using the Mann-Whiney U-test (difference between two groups) or the Kruskal-Wallis nonparametric ANOVA (differences among three groups) followed by a Dunn's test. All the statistical analyses were conducted using GraphPad Prism 6 software (GraphPad, 
San Diego, CA, USA). The differences between two means were considered significant at $p \leq 0.05$.

\section{Results}

\subsection{Systemic Cu Dyshomeostasis and Impaired Olfactory Function Following CuD or} $\mathrm{CuO}$ Treatment

$\mathrm{CuD}$ and $\mathrm{CuO}$ treatments did not cause significant changes in rat body weight compared to controls (data presented in Figure S1). To demonstrate if treatment with $\mathrm{CuD}$ (AIN-93G CuD diet $+10 \mathrm{mg} / \mathrm{kg}$ TTM daily injection for 2 weeks) and $\mathrm{CuO}$ (normal AIN-93 diet $+3 \mathrm{mg} \mathrm{Cu} / \mathrm{kg}$ daily injection for 2 weeks) (Figure 1A) caused systemic Cu dyshomeostasis, AAS was utilized to quantify $\mathrm{Cu}$ concentrations in the CSF, serum, and plasma. $\mathrm{Cu}$ levels in the CSF, serum, and plasma of the $\mathrm{CuD}$ rats were significantly lower than controls, while significantly higher in the CuO-treated animals as compared to controls $(p<0.05$; Figure 1B). Further, our data revealed that blood $\mathrm{Cu}$ levels for all groups were more than one magnitude higher than their corresponding CSF Cu levels, indicating $\mathrm{Cu}$ homeostasis in the central milieu is tightly regulated by the blood-brain interfaces.

Upon confirmation of treatment-induced systemic $\mathrm{Cu}$ dyshomeostasis, a behavioral study was conducted to examine whether altered systemic $\mathrm{Cu}$ homeostasis affected olfactory function. Specifically, olfactory function was assessed by the buried pellet test among the three groups. The latency to uncover buried pellet was similar in both $\mathrm{CuD}$ and $\mathrm{CuO}$ rats, about $240 \mathrm{~s}$; however, these values were significantly longer than that of control rats (about 60 seconds) ( $p<0.01$, Figure 2). In other words, $\mathrm{CuD}$ - or $\mathrm{CuO}$ - animals took approximately 4 times longer than controls to find the food pellet, suggesting that both $\mathrm{Cu}$ deficiency and overload conditions are capable of impairing olfactory sensory function.

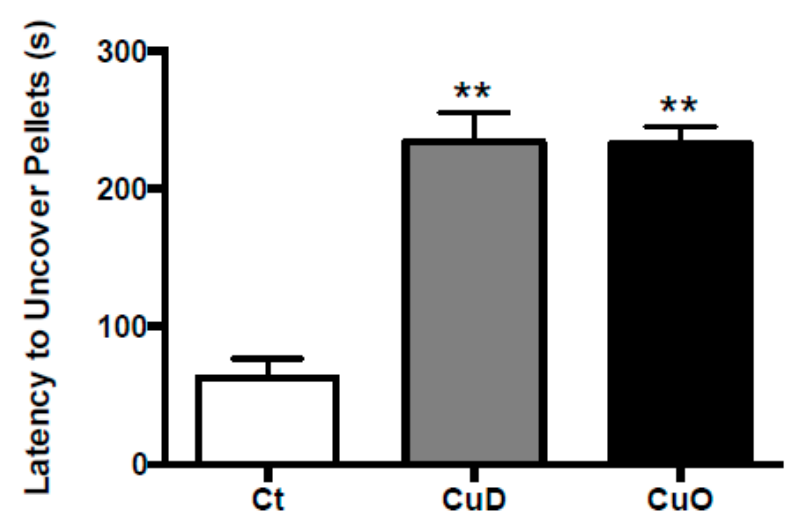

Figure 2. Buried pellet test to determine olfactory function. Rats were treated with $\mathrm{CuD}$ or $\mathrm{CuO}$ as described in Figure 1A. Tests were performed at the end of $\mathrm{CuD}$ or $\mathrm{CuO}$ treatment following three-day training and diet restriction. Data represents mean $\pm \mathrm{SEM}, \mathrm{n}=14$ /group. ${ }^{* *}: p<0.01$, as compared to the control group, using Kruskal-Wallis nonparametric ANOVA analysis. Ct: control; $\mathrm{CuD}$ : $\mathrm{Cu}$ deficiency; $\mathrm{CuO}$ : $\mathrm{Cu}$ overload.

\subsection{Altered Brain Regional $\mathrm{Cu}$ Levels Following $\mathrm{CuD}$ or $\mathrm{CuO}$ Treatment}

Previous studies from our laboratory have determined high $\mathrm{Cu}$ accumulation within the adult rat SVZ and OB [23,61], suggesting a crucial role of $\mathrm{Cu}$ in regulating adult neurogenesis, particularly in the SVZ-RMS-OB axis. As the first step to understand $\mathrm{Cu}$ mediated mechanisms of olfactory dysfunction, we measured Cu levels in the SVZ-RMS-OB regions (i.e., OB, RMS, SVZ and choroid plexus), to compare to other brain regions (i.e., striatum (STR), hippocampus (HP), frontal cortex (FC), and cerebellum (CB)), in $\mathrm{CuO}, \mathrm{CuD}$, and control rats. Our data revealed that the 2-week $\mathrm{CuD}$ treatment markedly reduced $\mathrm{Cu}$ levels in the OB, RMS horizontal arm (olfactory tract), and SVZ (Figure 3A). The 2-week $\mathrm{CuO}$ treatment only increased the $\mathrm{Cu}$ levels in the SVZ, but had no effect on Cu levels in OB and RMS $(p<0.001$, Figure $3 \mathrm{~A})$. 

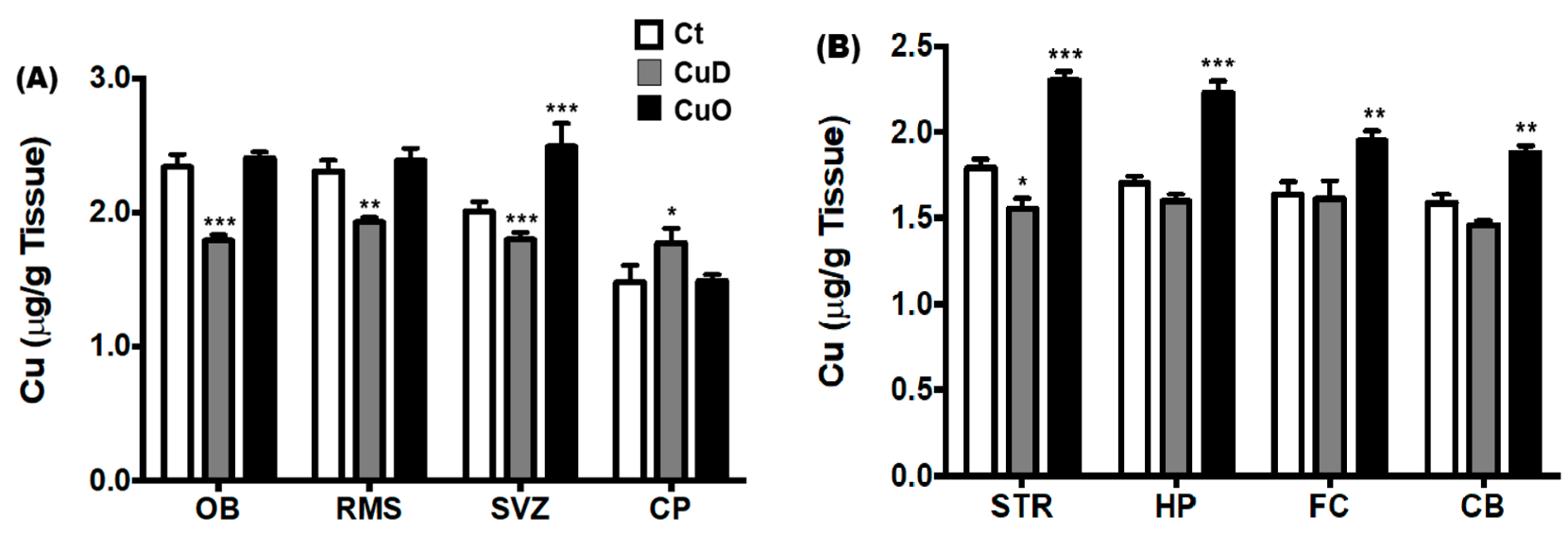

Figure 3. Brain regional $\mathrm{Cu}$ concentrations following $\mathrm{CuD}$ or $\mathrm{CuO}$ treatment. Brain tissues were dissected and analyzed for $\mathrm{Cu}$ by AAS. Data represents mean \pm SEM, $\mathrm{n}=6-7$ /group. ${ }^{*}: p<0.05,{ }^{* *}: p<0.01,{ }^{* * *}: p<0.001$, as compared to the correspondent $\mathrm{Ct}$ group, using one-way ANOVA analysis. (A). Cu levels in the SVZ-RMS-OB axis and choroid plexus. (B). $\mathrm{Cu}$ levels in selected brain regions. Ct: control; $\mathrm{CuD}$ : $\mathrm{Cu}$ deficiency; $\mathrm{CuO}$ : Cu overload; CSF: cerebrospinal fluid; OB: olfactory bulb; RMS: rostral migratory stream; SVZ: subventricular zone; CP: choroid plexus; STR: striatum; HP: hippocampus; FC: frontal cortex; CB: cerebellum.

Interestingly, a significant increase of $\mathrm{Cu}$ was found in the choroid plexus of $\mathrm{CuD}$ treated rats $(p<0.05)$, which was opposite to the general decreases observed in the OB, RMS, and SVZ (Figure 3A). As a barrier between the blood and CSF, it is possible that the blood-CSF barrier of the choroid plexus, in response to a decline in systemic $\mathrm{Cu}$ in $\mathrm{CuD}$, may retain or slow down the loss of $\mathrm{Cu}$ from the CSF to maintain CSF Cu homeostasis.

Altered systemic $\mathrm{Cu}$ homeostasis could also affect $\mathrm{Cu}$ levels in other brain regions such as in the STR, HP, FC, and CB. Our data showed that the 2-week CuD treatment caused a significant reduction of $\mathrm{Cu}$ only in STR ( $p<0.05$ compared with controls, Figure 3B), but not in other tested brain regions. In contrast, the 2-week $\mathrm{CuO}$ treatment caused significant $\mathrm{Cu}$ increases in all four tested brain regions as compared to controls $(p<0.01$, Figure $3 \mathrm{~B})$. It appeared as though regions associated with olfactory function and adult neurogenesis (i.e., OB, RMS, SVZ) tended to be more sensitive to the $\mathrm{CuD}$ treatment than other brain regions. Conversely, other brain regions tested (i.e., STR, HP, FC and CB) appeared to be more sensitive to the $\mathrm{CuO}$ treatment than the SVZ-RMS-OB regions.

\subsection{Altered Expressions of Neuronal Markers Following Systemic CuD or CuO Treatment}

The adult $\mathrm{OB}$ circuits consist of diverse types of neurons residing in each layer; among them, two neuronal types of particular interest are GABAergic neurons expressing glutamic acid decarboxylase protein 67-kDa isoform (GAD67) and dopaminergic neurons expressing tyrosine hydroxylase (TH) [62]. Our qPCR data showed that the expression of Gad67 mRNA in the OB was significantly upregulated by $40 \%$ and downregulated by $36 \%$ after the $\mathrm{CuD}$ and $\mathrm{CuO}$ treatment, respectively, when compared with controls $(p<0.01$, Figure $4 \mathrm{~A})$. Treatments with either $\mathrm{CuD}$ or $\mathrm{CuO}$, however, significantly reduced mRNA expression of Th in the OB, about $24 \%$ and $31 \%$ as compared to controls, respectively $(p<0.05$, Figure $4 \mathrm{~A})$. Hence, the disrupted $\mathrm{Cu}$ homeostasis appeared to affect the neuron populations in the adult $\mathrm{OB}$ circuits, which could influence the secretion of neurotransmitters and alter normal olfactory function.

New neurons in the adult OB are originated from the SVZ, where adult neural stem cells (i.e., Type-B cells expressing cellular marker Gfap) proliferate to generate rapidly dividing transient amplifying cells (i.e., Type-C cells expressing marker Nestin), which give rise to neuroblast cells (i.e., Type-A cells expressing $D c x$ ); these neuroblasts arrive the OB via the RMS and further differentiate into mature neurons (expressing marker NeuN) in OB [28,62-65]. To distinguish and identify the phenotypes of interested neural stem cells, neuroblasts, and neurons in the $\mathrm{OB}$ as influenced by disrupted adult neurogenesis in the 
SVZ-RMS-Ob axis, qPCR was used to quantify the expression of cellular mRNA markers of these neural stem and progenitor cells in the SVZ and OB.

(A)

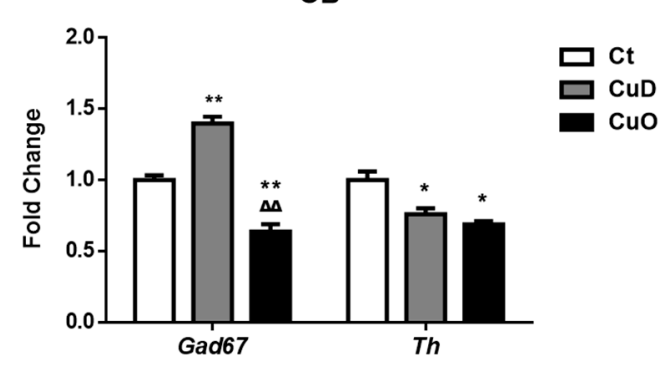

(C)

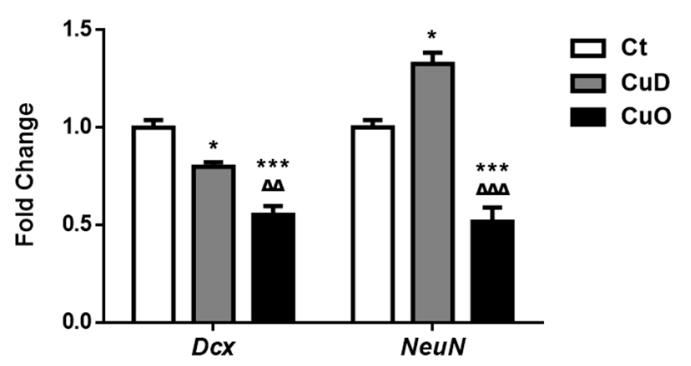

(B) SVZ

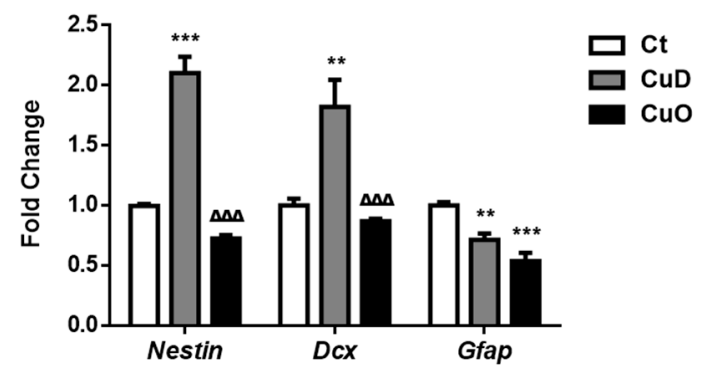

Figure 4. mRNA expression of neuronal markers following $\mathrm{CuD}$ or $\mathrm{CuO}$ treatment. The expression of neural markers was quantified by qPCR. (A). mRNA expression of Gad67 and Th in the OB. (B). mRNA expression of Nestin, Dcx, and Gfap in the SVZ. (C) mRNA expression of Dcx and NeuN in the OB. Data represents mean \pm SEM, $\mathrm{n}=6-7$ /group. *: $p<0.05$, ${ }^{* *}: p<0.01,{ }^{* * *}: p<0.001$, as compared to the correspondent Ct group; $\Delta \Delta: p<0.01, \Delta \Delta \Delta: p<0.001$, as compared to the correspondent $\mathrm{CuD}$ group; using one-way ANOVA analysis. $\mathrm{Ct}$ : control; $\mathrm{CuD}$ : $\mathrm{Cu}$ deficiency; $\mathrm{CuO}$ : $\mathrm{Cu}$ overload; SVZ: subventricular zone; OB: olfactory bulb.

Our data showed that the mRNA expression of Nestin and Dcx in the SVZ was significantly upregulated by 2.1- and 1.8-fold, respectively, following 2-week $\mathrm{CuD}$ treatment as compared to controls $(p<0.01$, Figure $4 \mathrm{~B})$; however, the $\mathrm{CuO}$ treatment did not affect mRNA expression of Nestin and Dcx in the SVZ (Figure 4B). These alterations in Nestin and $D c x$ suggest that the $\mathrm{CuD}$ condition stimulates the proliferation of Type-C transient cells and Type-A neuroblasts, while these stem cells appear to tolerate $\mathrm{CuO}$.

Interestingly, both $\mathrm{CuD}$ and $\mathrm{CuO}$ treatments significantly suppressed the mRNA expression of Gfap in the SVZ, a marker for Type-B progenitor cells, as compared to controls $(p<0.01$, Figure $4 \mathrm{~B})$. The results indicate that a balanced $\mathrm{Cu}$ homeostasis is essential to maintain the normal proliferation behavior of the abundant GFAP(+) Type B stem cells in the SVZ.

In the $\mathrm{OB}$ tissue, both in vivo $\mathrm{Cu}$ deficient and overload treatments resulted in a marked inhibition in the mRNA expression of neuroblast marker Dcx by $20 \%$ and $45 \%$, respectively $(p<0.05$, Figure $4 \mathrm{C})$. Noticeably, the neuroblasts that were upregulated in the SVZ (Figure 4A) did not seem to arrive or survive in the OB after CuD treatment (Figure 4C). In comparison to control rats, the NeuN mRNA expression level in the OB after $\mathrm{CuD}$ treatment was significantly increased by $33 \%$, and yet a significant reduction of $\mathrm{NeuN}$ mRNA expression by $48 \%$ was observed in the OB of CuO-treated animals $(p<0.05$, Figure $4 \mathrm{C}$ ). These findings imply that an altered systemic $\mathrm{Cu}$ status may cause aberrant regulation of multiple processes contributing to disruption of proliferation, migration, and possibly differentiation of $\mathrm{NeuN}(+)$ neurons from the SVZ-originated DCX(+) neuroblasts in the OB. 


\subsection{Altered NSPC Proliferation in Adult SVZ Following Systemic CuD or CuO Treatment}

To directly observe the impact of systemic $\mathrm{Cu}$ disorders on the proliferation of neural stem progenitor cells in the adult $\mathrm{SVZ}, \mathrm{CuD}$ and $\mathrm{CuO}$ rats received a single ip. injection of the proliferation marker BrdU $(100 \mathrm{mg} / \mathrm{kg})$. Brain tissues were dissected $4 \mathrm{~h}$ later to trace newly generated proliferating cells (Figure 1A). Confocal images demonstrated the number of $\mathrm{BrdU}(+)$ proliferating cells alongside the SVZ were increased in $\mathrm{CuD}$ animals compared to controls; whereas $\mathrm{BrdU}(+)$ cells were reduced in the $\mathrm{SVZ}$ of $\mathrm{CuO}$ compared to controls (Figure 5A).
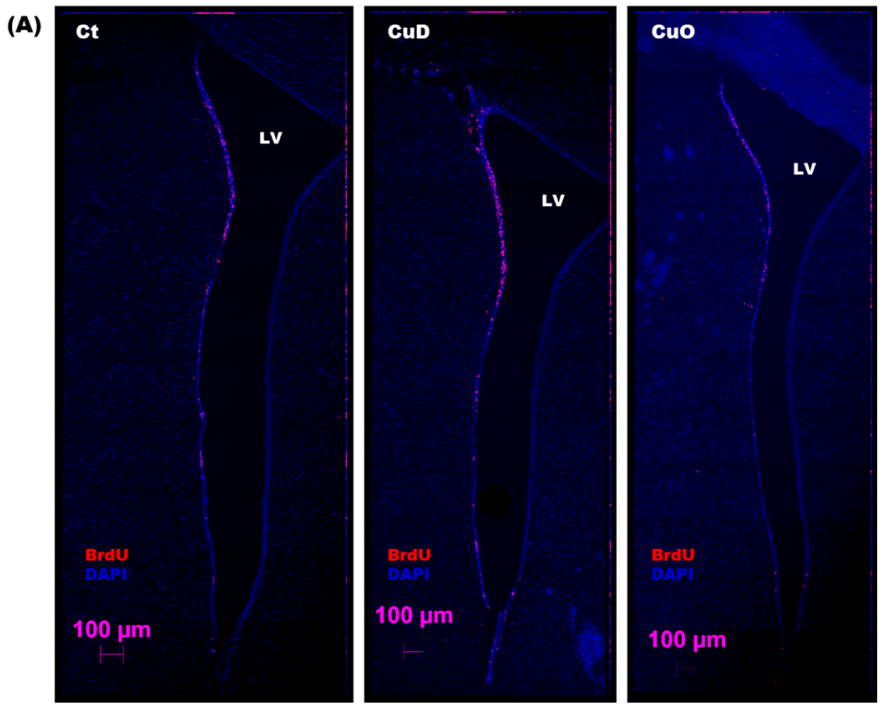

(B)

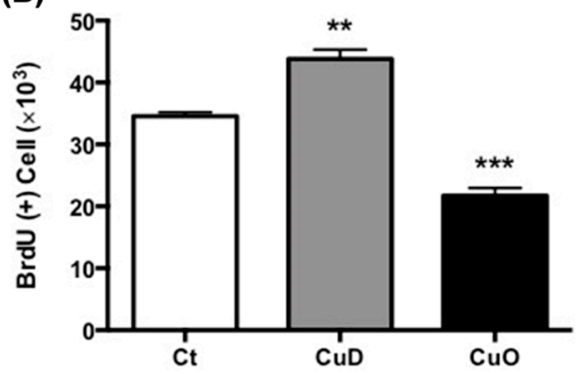

Figure 5. Confocal imaging study of proliferating NPSCs in the SVZ following CuD or CuO treatment. (A). Representative confocal images of the left coronal SVZ with BrdU (red signal)/DAPI (blue signal) staining. Scale bar $=250 \mu \mathrm{m}$. (B). BrdU(+) cell counts in the SVZ. Data represent mean \pm SEM, $\mathrm{n}=3-4$ /group. ${ }^{* *}: p<0.01,{ }^{* * *}: p<0.001$, as compared with the correspondent Ct group; using one-way ANOVA analysis.

By counting $\mathrm{BrdU}(+)$ proliferating cells in $\mathrm{SVZ}$, our results showed that $\mathrm{CuD}$ and $\mathrm{CuO}$ had the opposite effect by promoting and reducing the proliferation of NSPCs, respectively $(p<0.01$, Figure 5B). Thus, this evidence supports the view that $\mathrm{Cu}$ acts on a yet-to-beidentified regulatory mechanism by controlling adult neurogenesis in the SVZ, ultimately affecting olfactory function.

\subsection{Neurochemical Imbalance Following Systemic $\mathrm{CuD}$ or $\mathrm{CuO}$ Treatment}

Neuronal active chemicals such as GABA, glutamate, and catecholamines are vital in regulating olfactory function [66,67]. To investigate the influence of systemic $\mathrm{Cu}$ dyshomeostasis on the neurochemical balance of specific brain regions, a well-established HPLC method was used to determine levels of GABA, glutamate, and monoamines (i.e., DA, DOPAC, NE, 5-HT, 5-HIAA, and HVA) in the SVZ and OB in comparison to the striatum and hippocampus, following the 2-week $\mathrm{CuD}$ or $\mathrm{CuO}$ treatments. GABA levels of the 
CuD-treated animals were determined to be largely unchanged; the same results were observed in the $\mathrm{CuO}$-treated animals, except for a marked increase, about two folds, in the $\mathrm{OB}$, as compared to controls ( $p<0.001$, Figure $6 \mathrm{~A}$ ). Although no statistical significance was detected, there appeared to be an increased trend of GABA levels in the CuO-treated SVZ (Figure 6A).

(A)

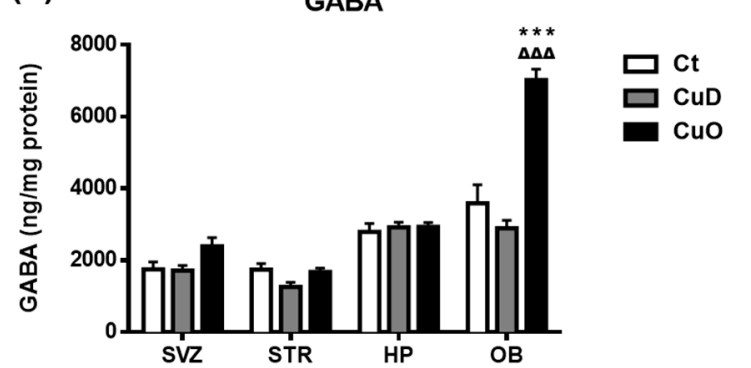

(B)

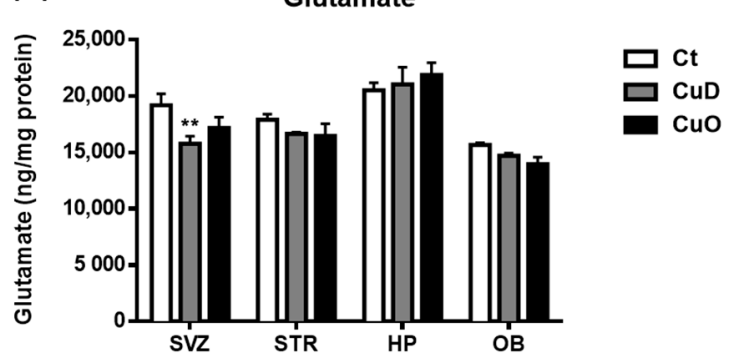

Figure 6. Changes of GABA and glutamate levels in selected brain regions following CuD or CuO treatment. Brain neuroactive amino acids were measured by HPLC. (A). Brain regional GABA levels. (B) Brain regional glutamate levels. Data represents mean $\pm \mathrm{SEM}, \mathrm{n}=6-7$ /group. ${ }^{* *}: p<0.01,{ }^{* * *}: p<0.001$, as compared to the correspondent Ct group; $\Delta \Delta \Delta: p<0.001$, as compared with the correspondent $\mathrm{CuD}$ group; using one-way ANOVA analysis. Ct: control; $\mathrm{CuD}$ : $\mathrm{Cu}$ deficiency; CuO: Cu overload; SVZ: subventricular zone; STR: striatum; HP: hippocampus; OB: olfactory bulb.

The levels of glutamate in all tested brain regions under either $\mathrm{CuD}$ or $\mathrm{CuO}$ condition did not change significantly, except for a significantly lower glutamate level in the SVZ of CuD rats $(p<0.01$, Figure $6 \mathrm{~B})$.

Among the monoamines examined, neither $\mathrm{CuD}$ nor $\mathrm{CuO}$ treatment had any significant impact on the DA levels (Figure 7A), while both treatments significantly reduced DOPAC levels, as compared to controls $(p<0.05$, Figure 7B). Interestingly, both DA and DPOAC contents were at similar levels in the SVZ and striatum, which were a magnitude higher than those in the hippocampus and OB (Figure 7A,B). The turnover rates of DA were significantly reduced in both of the $\mathrm{CuD}$ - and $\mathrm{CuO}$ - treated rats, as compared to controls, in all tested brain regions except for the $\mathrm{OB}$ of $\mathrm{CuD}$-treated rats $(p<0.05$, Figure $7 \mathrm{C})$. In addition, the DA turnover rates in the hippocampus and $\mathrm{OB}$ were about one magnitude higher than those in the SVZ and striatum, which differed from the opposite magnitude pattern observed in DA and DOPAC (Figure 7A vs. Figure 7C). Similar to the pattern in DOPAC (Figure 7B), the levels of HVA, a major catecholamine metabolite, were significantly reduced in all tested brain regions following either $\mathrm{CuD}$ or $\mathrm{CuO}$ treatment, except for the $\mathrm{CuO}$-treated hippocampus, as compared to controls $(p<0.05$, Figure $7 \mathrm{D})$. These findings indicate that systemic $\mathrm{Cu}$ dyshomeostasis disturbs DA pathways by interrupting DOPAC balance.

5 -HT status was also quantified in the selected brain regions. Following $\mathrm{CuD}$ or $\mathrm{CuO}$ treatment, a significant increase in 5-HT was observed in the CuO-treated SVZ $(p<0.05$, Figure 7E). However, both treatments resulted in a marked reduction in striatum 5-HT levels, while $\mathrm{CuO}$ treatment reduced OB 5-HT levels $(p<0.05$, Figure 7E). The levels of 5-HIAA, a major metabolite of 5-HT, in the SVZ, OB and striatum were also significantly reduced, as compared to controls, following both $\mathrm{CuD}$ and $\mathrm{CuO}$ treatments $(p<0.05$, Figure 7F). Noticeably, only in the OB were the turnover rates of 5-HT significantly slower than those of the control $\mathrm{OB}$ in both $\mathrm{CuD}$ and $\mathrm{CuO}$ treated animals $(p<0.05$, Figure 7G). Taken together, these findings imply that the systemic $\mathrm{Cu}$ dyshomeostasis disrupts 5-HT balance and its metabolism in the SVZ-OB axis of the rat brain. 
(A)

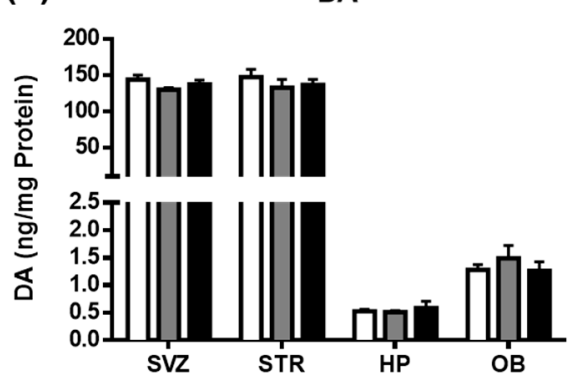

(C)

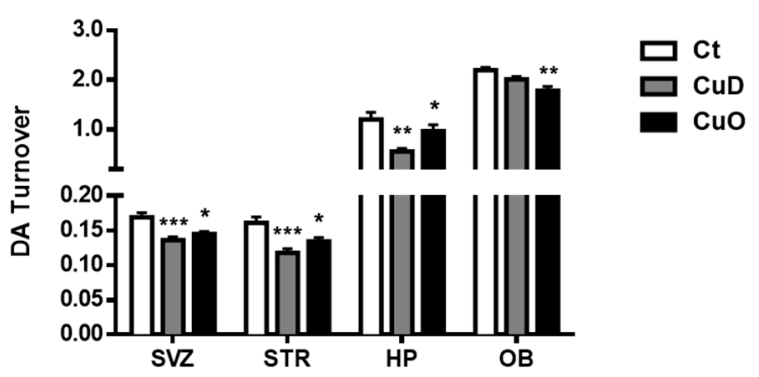

(E)

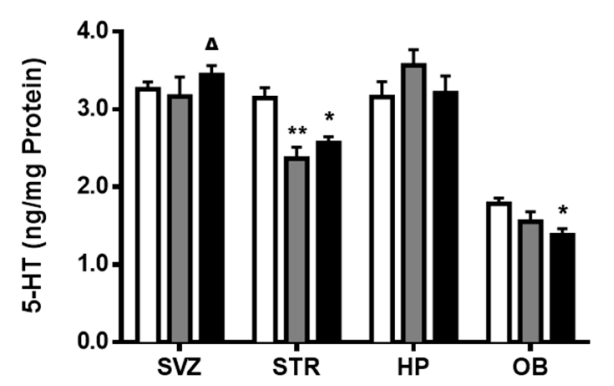

(G)
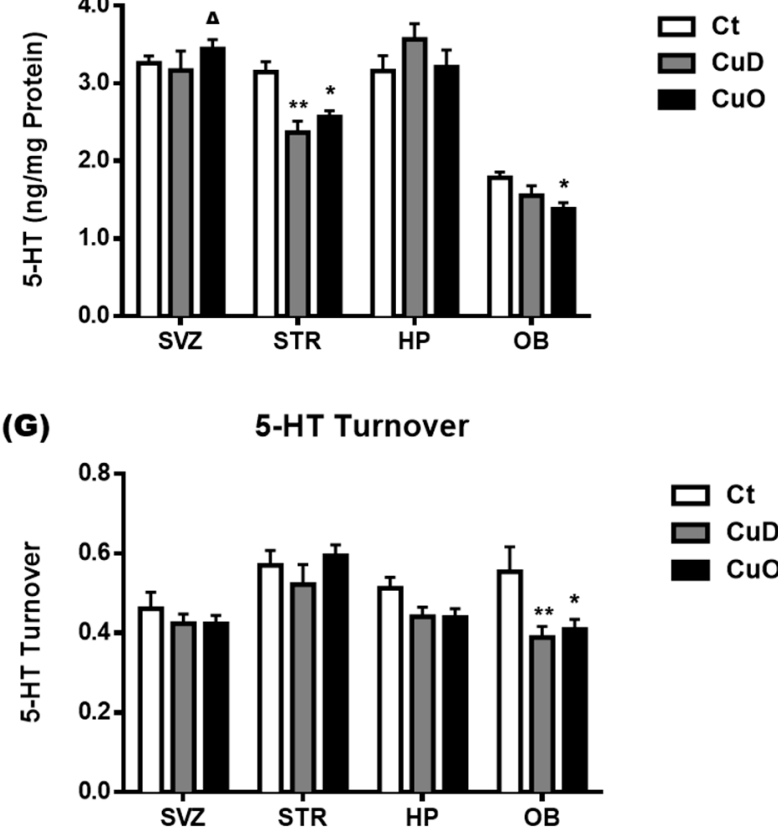

(B)

DOPAC

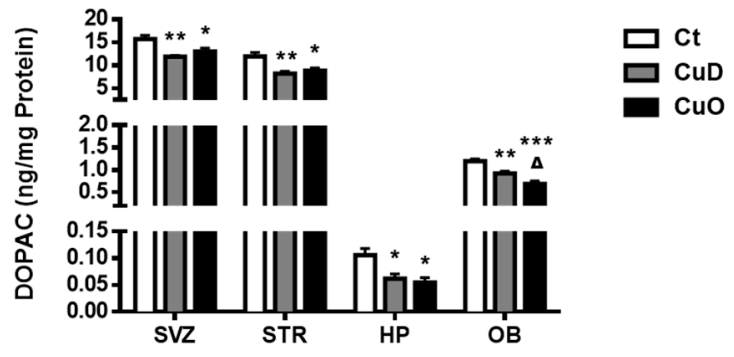

(D)

HVA

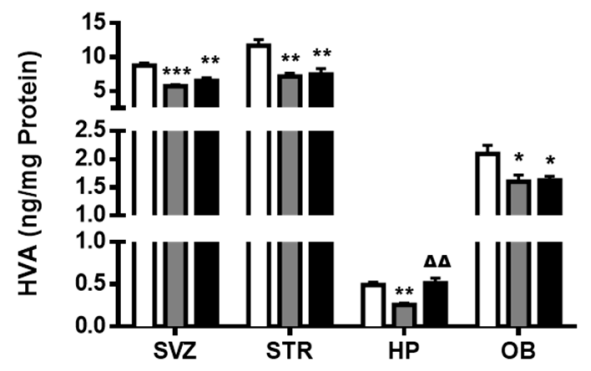

(F)

5-HIAA

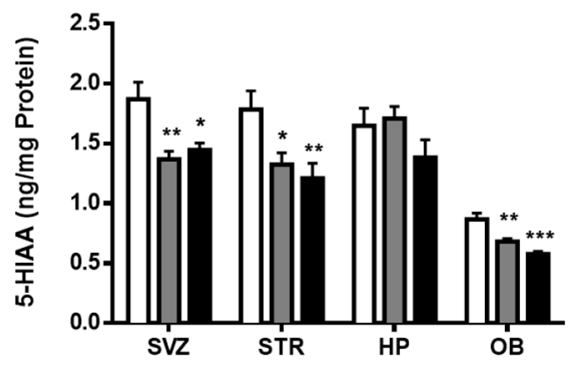

(H)

NE

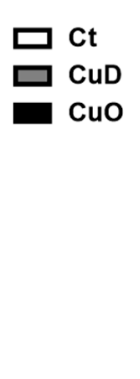

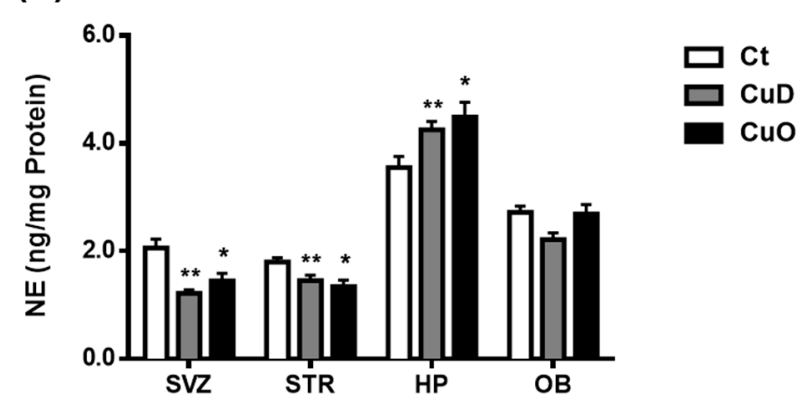

Figure 7. Changes of monoamine levels in selected brain regions following $\mathrm{CuD}$ or $\mathrm{CuO}$ treatment. Brain monoamine levels were assayed by HPLC. (A). Brain regional DA levels. (B). Brain regional DOPAC levels. (C). DA turnover in different brain regions. (D). Brain regional HVA levels. (E). Brain regional 5-HT levels. (F) Brain regional 5-HIAA levels. (G). 5-HT turnover rates in different brain regions. (H). Brain regional NE levels. Data represents mean $\pm \mathrm{SEM}$, $\mathrm{n}=6-7$ /group. ${ }^{*}: p<0.05,{ }^{* *}: p<0.01,{ }^{* * *}: p<0.001$, as compared with the correspondent Ct group; $\Delta: p<0.05, \Delta \Delta$ : $p<0.01$, as compared with the correspondent $\mathrm{CuD}$ group; using one-way ANOVA analysis. Ct: control; CuD: Cu deficiency; $\mathrm{CuO}$ : $\mathrm{Cu}$ overload; SVZ: subventricular zone; STR: striatum; HP: hippocampus; OB: olfactory bulb; DA: dopamine; DOPAC: 3,4-Dihydroxyphenylacetic acid; HVA: homovanillic acid; 5-HT: 5-hydroxytryptamine or serotonin; 5-HIAA: 5-hydroxyindoleacetic acid; NE: norephinephrine. 
The systemic $\mathrm{CuD}$ and $\mathrm{CuO}$ treatments also significantly reduced NE levels in the SVZ and striatum but did not affect NE levels in the OB $(p<0.05$, Figure $7 \mathrm{H})$. Interestingly, NE levels in the hippocampus were much higher than in other tested brain regions, and treatment with either $\mathrm{CuD}$ or $\mathrm{CuO}$ significantly increased $\mathrm{NE}$ levels in the hippocampus as compared to controls ( $p<0.05$, Figure $7 \mathrm{H}$ ). These NE alterations induced by systemic $\mathrm{Cu}$ disorders suggest that a stable $\mathrm{Cu}$ homeostasis may attribute to maintaining the balance of $\mathrm{NE}$ in the brain.

\subsection{Altered Expression of Cu Transport-Associated mRNA Following Systemic CuD or $\mathrm{CuO}$ Treatment}

$\mathrm{Cu}$ levels in the CSF and brain regions are regulated by $\mathrm{Cu}$ transporters and intracellular $\mathrm{Cu}$ binding proteins [39]. Altered $\mathrm{Cu}$ levels following $\mathrm{CuD}$ and $\mathrm{CuO}$ treatments observed in Figure 3 could result from the up- or down-regulation of these Cu regulatory proteins. Thus, we used qPCR to quantify $\mathrm{Cu}$ transporters (i.e., CTR1, DMT1) and $\mathrm{Cu}$ binding proteins (i.e., metallothionein isoforms MT1a, MT2a and MT3) in the SVZ, OB and choroid plexus, a tissue that is immediately adjacent to the SVZ and regulates $\mathrm{Cu}$ transport between the blood and CSF. After normalizing with the internal reference $A c t b$, the delta-delta cycle time $(\Delta \Delta \mathrm{Ct})$ values of $C t r 1, D m t 1, M t 1 a, M t 2 a$, and $M t 3$ in these selected brain regions were presented in Figure 8. In control animals without treatment, the choroid plexus expressed Ctr1 and Dmt1 mRNA at a level more than 3-5 times higher than the expression level in the control OB; moreover, Ctr1 mRNA levels were about 17-fold and 7-fold higher than Dmt1 in the control plexus and OB tissues, respectively $(p<0.001$, Figure $8 \mathrm{~A}$ ). The high mRNA abundance of the $\mathrm{Cu}$ transporting protein CTR1 in the choroid plexus suggests that CTR1 is essential in the transport and regulation of $\mathrm{Cu}$ ions between the blood and CSF, which may influence the $\mathrm{Cu}$ content of brain regions.

(A)

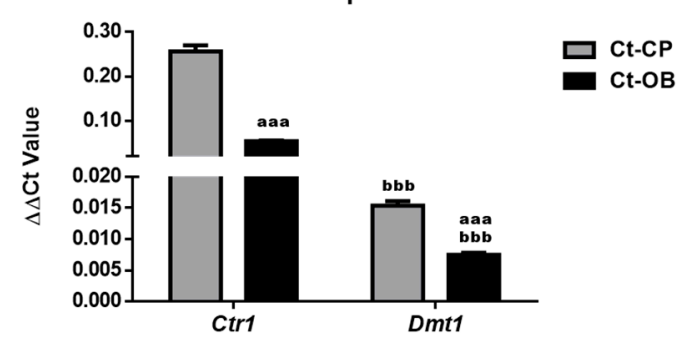

(B)

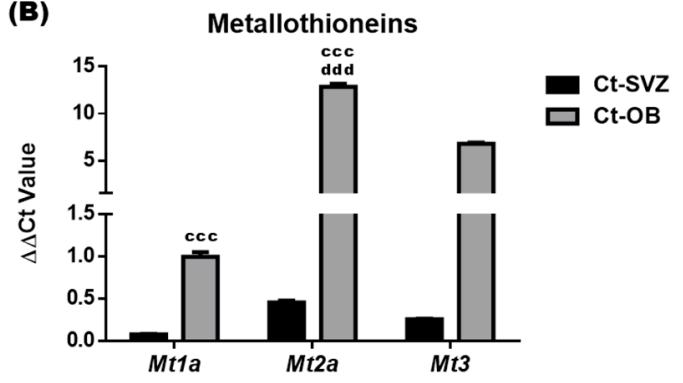

Figure 8. mRNA expression of $\mathrm{Cu}$ regulatory proteins in control rats. Expressions of mRNA encoding Cu regulatory proteins were quantified by qPCR. (A). $\Delta \Delta \mathrm{Ct}$ values of $\mathrm{Cu}$ transporters $\mathrm{Ctr1}$ and $\mathrm{Dmt} 1$ in the control $\mathrm{CP}$ and $\mathrm{OB}$. (B). $\Delta \Delta \mathrm{Ct}$ values of metallothioneins Mt1a, Mt2a, and Mt3 in the control SVZ and OB. Data represents mean \pm SEM, $\mathrm{n}=6-7 /$ group. aaa: $p<0.001$, as compared with the Ct-CP; bbb: $p<0.001$, as compared with the correspondent Ctr1 $\Delta \Delta \mathrm{Ct}$ values of the same tissue; ccc: $p<0.001$, as compared with the Ct-SVZ; ddd: $p<0.001$, as compared with the correspondent Mt1a $\Delta \Delta \mathrm{Ct}$ values of the same tissue. SVZ: subventricular zone; OB: olfactory bulb.

The mRNA expression level of metallothionein proteins (MT1a, MT2a and MT3) in the control OB were 12-, 28-, and 26-times higher than the expression level detected in the control SVZ, respectively $(p<0.001$, Figure 8B). Such enhanced levels indicated that the OB could accumulate higher a level of $\mathrm{Cu}$ ions than the SVZ. Among those three metallothionein genes in both control SVZ and OB tissues, Mt2a had the highest mRNA expression, followed by Mt3 and Mt1a (Figure 8B), implying that MT2a and MT3 serve as the key $\mathrm{Cu}$ storage protein in both tissues.

The 2-week $\mathrm{CuD}$ and $\mathrm{CuO}$ treatments significantly downregulated and upregulated Ctr 1 mRNA expressions by $42 \%$ and $83 \%$ in the choroid plexus, respectively, as compared to controls ( $p<0.01$, Figure 9A). In contrast to the transcriptional changes of Ctr1, the expression of Dmt1 mRNA in the choroid plexus was markedly upregulated and downregulated after $\mathrm{CuD}$ - and $\mathrm{CuO}$ treatments, respectively $(p<0.01$, Figure 9B). Specifically 
in the $\mathrm{OB}$, both $\mathrm{Ctr} 1$ and Dmt1 mRNA expressions were downregulated under the CuDor $\mathrm{CuO}$ - condition ( $p<0.01$, Figure 9A,B). These findings suggest that CTR1 and DMT1 appear to respond to $\mathrm{CuD}$ and $\mathrm{CuO}$ conditions in an entirely different manner in the blood-CSF barrier provided by the choroid plexus. Further, systemic $\mathrm{CuD}$ and $\mathrm{CuO}$ disrupt $\mathrm{Cu}$ transporters not only in $\mathrm{Cu}$ transporting tissue, i.e., the choroid plexus, but also in the $\mathrm{OB}$ which regulates olfactory function.
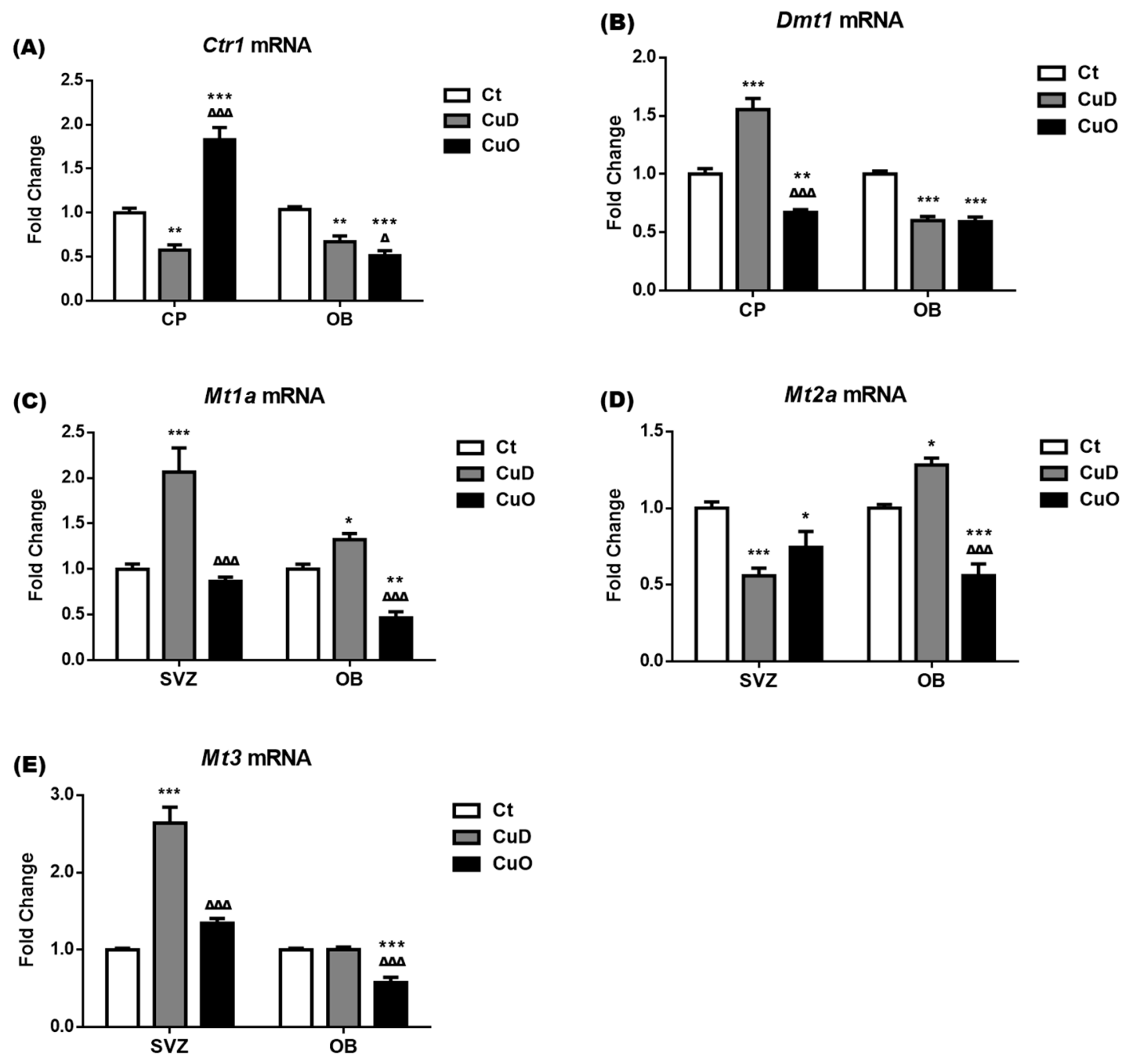

Figure 9. Expression of $\mathrm{Cu}$ regulatory mRNAs following $\mathrm{CuD}$ or $\mathrm{CuO}$ treatment. Expressions of mRNAs encoding $\mathrm{Cu}$ regulatory proteins were quantified by qPCR. (A). Ctr1 mRNA expressions in the choroid plexus (CP) and OB. (B). Dmt1 mRNA expressions in the CP and OB. (C). Mt1a mRNA expressions in the SVZ and OB. (D) Mt2a mRNA expressions in the SVZ and OB. (E) Mt3 mRNA expressions in the SVZ and OB. Data represents mean \pm SEM, $\mathrm{n}=6-7 /$ group. ${ }^{*}: p<0.05$, ${ }^{* *}: p<0.01,{ }^{* * *}: p<0.001$, as compared to the correspondent Ct group; $\Delta: p<0.05, \Delta \Delta \Delta: p<0.001$, as compared with the correspondent $\mathrm{CuD}$ group; using one-way ANOVA analysis. Ct: control; $\mathrm{CuD}$ : $\mathrm{Cu}$ deficiency; $\mathrm{CuO}$ : $\mathrm{Cu}$ overload; SVZ: subventricular zone; OB: olfactory bulb.

The 2-week CuD treatment significantly upregulated the mRNA expression of $M t 1 a$ and $M t 3$ in the SVZ by 2.1 and 2.6 folds respectively, as compared to the control SVZ $(p<0.001$, Figure 9C,E). However, Mt2a mRNA expression in the SVZ was significantly downregulated by both $\mathrm{CuD}$ and $\mathrm{CuO}$ treatments $(p<0.05$, Figure 9D). In the $\mathrm{OB}, \mathrm{CuD}$ treatment significantly induced the mRNA expression of $M t 1 a$ and $M t 2 a$ by $32 \%$ and $28 \%$, respectively, without affecting the expression of $M t 3$, while the $\mathrm{CuO}$ treatment resulted in significant downregulation of all three genes by $53 \%$ in $M t 1 a, 44 \%$ in $M t 2 a$, and $42 \%$ in $M t 3$, as compared to those of controls $(p<0.05$, Figure 9C-E). The downregulation of 
Ctr1, Dmt1, Mt1a, Mt2a, and $M t 3$ in the $\mathrm{OB}$ of $\mathrm{CuO}$ animals seems likely to indicate that this is a mechanism to regulate and maintain local $\mathrm{Cu}$ homeostasis in the $\mathrm{OB}$ under the systemic $\mathrm{Cu}$ overload condition, which is in agreement with AAS data where no significant $\mathrm{Cu}$ accumulation was observed in the $\mathrm{OB}$ of $\mathrm{CuO}$ rats (Figure $3 \mathrm{~A}$ ).

\section{Discussion}

The question of whether distorted $\mathrm{Cu}$ homeostasis affects olfactory function has long been unanswered. The current in vivo study provides first-hand evidence that systemic $\mathrm{Cu}$ dyshomeostasis, specifically $\mathrm{Cu}$ deficiency or $\mathrm{Cu}$ overload, likely impairs olfactory function by diminishing the animal's natural sensation of smelling and food-finding. This impaired olfactory function under $\mathrm{Cu}$ dyshomeostasis is believed to be due, at least in part, to the disruption of $\mathrm{Cu}$-mediated regulation of adult neurogenesis in the SVZ-RMS-OB axis. This conclusion is supported by several lines of observations. First, both $\mathrm{CuD}$ and $\mathrm{CuO}$ result in treatment-dependent reduction or elevation of $\mathrm{Cu}$ levels in local brain regions critical to olfactory function. Second, the locally altered $\mathrm{Cu}$ levels in the OB, RMS and SVZ apparently disrupt populations of GABA and DA neurons in $\mathrm{OB}$, along with altering the expression of cellular markers for proliferation, migration, and differentiation of neural stem and progenitor cells in the SVZ-RMS-OB axis. Third, $\mathrm{CuD}$ and $\mathrm{CuO}$ treatments cause abnormal changes in neuroactive amino acids and monoamines in critical brain areas that regulate olfactory function. Finally, in vivo $\mathrm{Cu}$ dyshomeostasis clearly impairs mechanisms whereby $\mathrm{Cu}$ in the central milieus is regulated by transporters across brain barriers and storage proteins in local tissues. These observations support an essential role of $\mathrm{Cu}$ in adult neurogenesis and pertinent normal olfactory function.

Olfactory impairments, such as deficits in odor identification, detection, and discrimination, are found in patients with PD and AD [35,36,68,69]. Particularly with regards to $\mathrm{PD}$, the olfactory dysfunction is one of the initial symptoms occurring years before motor symptoms and cognitive deficiency become evident. Thus, olfactory dysfunction has been suggested as a clinical indicator of the early stages of PD and also as an indicator of disease progression aiding in diagnosis [70]. The role of $\mathrm{Cu}$ in regulating olfactory function in healthy and disease conditions remains largely unknown. However, a few studies utilizing zebrafish models have provided the initial evidence to support $\mathrm{Cu}$ exposure and ensuing impaired olfaction. Specifically, they demonstrate $\mathrm{Cu}$-mediated loss of behaviors critical to fish involving olfaction, such as predator avoidance, prey capture, mate selection, social behavior and migration [71-73].

Works by Baldwin et al., [71] report a Cu-dose-dependent inhibition of olfactorymediated behaviors that are critical for the survival and migratory success of wild salmonids. By using the electro-olfactography to measure the level of olfactory dysfunction in zebrafish models, Dew et al. [74] reveal that exposure to a low, ecologically relevant $\mathrm{Cu}$ concentration causes a significant inhibition of olfactory activities. Julliard et al. (1996) also observe that olfactory deficits in zebrafish caused by $\mathrm{Cu}$ exposure can trigger aberrant olfactory neurogenesis, affecting both mature and immature neurons; the authors conclude that these responses are related to receptor-mediated cell death in the OB. Our observation of diminished olfactory function following systemic $\mathrm{Cu}$ dyshomeostasis in rats is in a good agreement with these previous reports from fish studies. Although little is known about the precise location of $\mathrm{Cu}$ in the $\mathrm{OB}$, previous studies have shown that the mammalian $\mathrm{OB}$ has high concentrations of zinc $(\mathrm{Zn})$ and $\mathrm{Cu}$ compared to other CNS regions [75,76]. Further, $\mathrm{Zn}$ is identified to exist primarily in olfactory sensory neuron terminals in the glomerular layer and neuron terminals in the granule cell layer [77-79]. With the close companionship that exists between $\mathrm{Zn}$ and $\mathrm{Cu}, \mathrm{Cu}$ would likely concentrate within the olfactory sensory neurons as well. In addition, in vitro studies have observed that $\mathrm{Cu}$ influences the excitability of rat $\mathrm{OB}$ neurons by multiple mechanisms such as eliminating GABA-mediated spontaneous inhibitory postsynaptic potential, blocking the spontaneous glutamate-mediated excitatory synaptic activity, inhibiting sodium channels, and delayed rectifier-type potassium channels, etc. [80-83]. 
Several mechanisms may underscore Cu's disruptive impact on olfactory function. The altered $\mathrm{Cu}$ level in critical brain regions relevant to olfaction (i.e., OB, SVZ, RMS) may cause alterations in adult neurogenesis in these areas affecting olfaction. This was suggested based on increases in proliferating markers in the SVZ of CuD and inhibition of these markers in the SVZ of CuO. It is possible that the loss of olfactory neurons may trigger adult neurogenesis in the SVZ-RMS-OB system by increasing the proliferation of olfactory NSPCs to replace the damaged sensory neurons in the OB. A zebrafish study demonstrates that $\mathrm{Cu}$ exposure can cause olfactory dysfunction and induce abnormal neurogenesis [4]. Moreover, a recent study by Ma et al. [84] demonstrates that transgenic zebrafish with diminished olfactory sensory neurons display an increased BrdU labeling after $\mathrm{Cu}$ exposure. Their further olfactory behavioral analyses reveal that the initial loss comes with a later restoration of olfactory neurons, which likely compensates for $\mathrm{Cu}-$ induced olfactory dysfunction. Our current study extended the research focus beyond the OB by examining responses throughout the entire SVZ-RMS-OB axis. Our data clearly establishes that the impact of systemic $\mathrm{Cu}$ disorder is not solely limited to the $\mathrm{OB}$, but rather adversely affects processes of neurogenesis from its origin in the SVZ and along the SVZ-RMS-OB axis.

Noticeably, the Cu concentration in the SVZ is about 20-30 times higher than other brain regions, CSF, and plasma $[19,23]$. In our previous publications, we hypothesized that such a high $\mathrm{Cu}$ status in the SVZ may be necessary to maintain adult neurogenesis in this proliferative niche $[19,24,61]$. Although the amount of $\mathrm{Cu}$ necessary to regulate proliferation, differentiation, and migration of NSPCs in the SVZ-RMS-OB axis remains unknown, our current data appear to suggest that a disrupted $\mathrm{Cu}$ homeostasis impacts adult neurogenesis. Specifically, a reduced $\mathrm{Cu}$ status in the SVZ, as a result of $\mathrm{CuD}$, may directly activate adult neurogenesis in the SVZ. This postulation was supported by the observation that Nestin(+) Type-C transit-amplifying cells and DCX(+) Type-A migratory neuroblasts were elevated following $\mathrm{CuD}$ treatment. In contrast, under high $\mathrm{Cu}$ conditions such as in the $\mathrm{CuO}$ animals, proliferation of GFAP(+) Type-C astrocytic stem cells and differentiation of NSPCs to $\mathrm{NeuN}(+)$ immature neurons were inhibited in the OB, pointing to an impaired adult neurogenesis. These observations prompt a new hypothesis that $\mathrm{Cu}$ in the SVZ functions as a biological "switch" that regulates adult neurogenesis. Specifically, adult neurogenesis is activated when $\mathrm{Cu}$ levels are low and inhibited when $\mathrm{Cu}$ levels are high. The molecular and cellular mechanisms by which $\mathrm{Cu}$ acts on its putative ligands thus warrant further investigation.

Our data determined an increased DCX expression in the SVZ and yet a reduced $\mathrm{DCX}$ expression in the $\mathrm{OB}$ of $\mathrm{CuD}$ rats. This could be due to unsuccessful arrival and/or reduced survival of SVZ-originated DCX(+) neuroblasts in the OB following CuD treatment. However, the possibility that some of the SVZ-originated neuroblasts may have differentiated into mature neurons at the time of experimentation cannot be ruled out. In fact, the latter hypothesis is partly supported by the observation of increased NeuN expression in the $\mathrm{OB}$ of the same $\mathrm{CuD}$ animals. Nonetheless, our observations support the disrupted proliferation, migration, and neuronal cell populations in the adult SVZ-RMS-OB system following disruption of $\mathrm{Cu}$ homeostasis.

Abnormal changes in neuroactive amino acids and monoamines in brain regions critical to olfaction may underlie $\mathrm{Cu}$ dyshomeostasis-associated olfactory dysfunction. Especially compelling in the $\mathrm{CuO}$ condition is the large increase in olfactory GABA and decreases in monoamine neurotransmitters/metabolites which could impact olfactory dysfunction. Reports in literature have suggested that $\mathrm{Cu}$ is an essential cofactor for at least twelve mammalian enzymes including dopamine beta-mono-oxygenase and actively participates in the synthesis of catecholamines, neuropeptide, and tyrosinase [47,85]. Reduced dopamine has been associated with dietary $\mathrm{Cu}$ deficiency in humans [86]. In addition, $\mathrm{Cu}$ ions have been found in synapses where they are released into the synaptic cleft, bind to neurotransmitters, and regulate activities of postsynaptic receptors, such as GABA receptors $[6,87,88]$. Thus, it seems likely the neurochemical imbalance observed in the SVZ, 
striatum, and hippocampus in the current study may be a direct result of altered Cu levels in these brain regions with ensuing disruptions in yet-to-be-defined $\mathrm{Cu}$-sensitive pathways. These alterations may, in turn, underscore the motor and/or neurobehavioral dysfunction following systemic $\mathrm{Cu}$ dyshomeostasis.

Overall, $\mathrm{Cu}$ dyshomeostasis produces complex changes in neurotransmission that need to be further investigated. Given the effects on neurotransmitter metabolites and turnover observed in many brain regions, it becomes critical to examine whether $\mathrm{Cu}$ dyshomeostasis directly affects enzymes involved in neurotransmitter metabolism and also whether neurotransmitter release is modulated. Here, our surprising finding is that both $\mathrm{Cu}$ overload and deficiency seemed to produce similar alterations in monoamine neurotransmitters. Thus, it may be that a metal imbalance (in this case $\mathrm{Cu}$ ) drives changes in neurotransmitter release/metabolism rather than their absolute levels. Specifically, increased or decreased levels of $\mathrm{Cu}$ do not produce differential effects but cause similar effects in regards to neurotransmitters. Data indicates an optimum threshold requirement that could be affecting two processes simultaneously: neurotransmitter release and metabolism.

Systemic $\mathrm{Cu}$ dyshomeostasis was determined to influence $\mathrm{Cu}$ levels in distinct local brain regions. Under normal physiological conditions, $\mathrm{Cu}$ is strictly regulated by a complex regulatory system involving membrane-bound $\mathrm{Cu}$ transporters, intracellular $\mathrm{Cu}$ chaperons, $\mathrm{Cu}$-binding storage proteins, and cuproenzymes [39]. $\mathrm{Cu}$ in the blood circulation is transported into the brain and CSF via the blood-brain barrier and blood-CSF barrier in the choroid plexus, respectively $[39,41,56]$. As a barrier between the blood and CSF, the choroid plexus regulates the CSF $\mathrm{Cu}$ homeostasis. A significant increase in $\mathrm{Cu}$ was observed in the plexus tissue of CuD-treated rats, while Cu levels in the OB, RMS, and SVZ decreased. This observation possibly indicates that the choroid plexus may respond to systemic $\mathrm{CuD}$ by retaining or reducing the loss of $\mathrm{Cu}$ to maintain $\mathrm{Cu}$ homeostasis in the CSF.

In the brain, $\mathrm{Cu}$ is unevenly distributed [13,89-93], varies among species [94-96], and changes during development and in neurodegenerative conditions [97-100]. Markedly higher levels of $\mathrm{Cu}$ are found in the substantia nigra, locus coeruleus, and hippocampus [91,101-103]. The current study shows a higher expression of $\mathrm{Cu}$ transport proteins in the choroid plexus, which regulates $\mathrm{Cu}$ transport between the blood and CSF, than other tested brain regions and a comparatively lower expression of $\mathrm{Cu}$ storage proteins. These observations confirm similar distribution patterns of $\mathrm{Cu}$ regulatory proteins in previous reports $[19,104,105]$. An increase in a major Cu storage protein MT3 in SVZ and MT2 in OB after $\mathrm{CuD}$ treatment may explain the higher $\mathrm{Cu}$ levels in these tissues, while a decreased MT2 and MT3 in the SVZ and OB following CuO treatment may underscore lower $\mathrm{Cu}$ levels in the SVZ and OB.

The current study has several limitations. First, determination of neuronal markers such as Dcx (for Type A migratory neuroblasts), Nestin (for Type C transit-amplifying cells), GFAP (for Type B astrocytic stem cells), and NeuN (for mature neurons) is a valid approach to reflect the status of adult neurogenesis in the SVZ-RMS-OB axis. Yet, a more direct approach pertains to counting specific cell types double-labeled with BrdU. Second, the changes of a group of $\mathrm{Cu}$ transport and storage proteins were assayed by qPCR. In our future studies, it is desirable to conduct confocal experiments to verify alterations in the expression of these $\mathrm{Cu}$ regulatory proteins.

Finally, the phospholipids, mainly phosphatidylcholine and phosphatidylethanolamine, account for $81 \%$ (by weight) of the total lipid in rat olfactory mucosa, playing an indispensable role in maintaining the normal olfaction [106]. Recent data have suggested that chronic $\mathrm{CuO}$ in rats causes brain redox imbalance by generating free radicals via phospholipid peroxidation [107]. The evidence to suggest an interaction between $\mathrm{Cu}$ dyshomeostasis and phospholipid disruption in OB remains elusive; however, such a hypothesis along with changed endocannabinoid levels deserves further exploration.

In summary, our results from the animal models of $\mathrm{Cu}$ deficiency and $\mathrm{Cu}$ overload demonstrate systemic $\mathrm{Cu}$ dyshomeostasis can cause olfactory dysfunction. Further, mechanistic investigation suggests altered $\mathrm{Cu}$ status in local brain areas critical to olfaction may 
disrupt adult neurogenesis in the SVZ-RMS-OB axis, which supplies newly proliferated and differentiated neurons to the OB. These observations provide the first evidence to support a critical role of $\mathrm{Cu}$ in adult neurogenesis and in regulating olfactory function.

Supplementary Materials: The following are available online at https:/ / www.mdpi.com/article/ 10.3390/biom11091315/s1, Figure S1: Record of rat body weights during the course of Cu treatment.

Author Contributions: Authors contributed to this work in their respective capacities as follows: Conceptualization, W.Z., J.C.; methodology, S.X.-F.A., S.F.; investigation, S.X.-F.A., Z.S.A.; resources, J.S., W.Z., J.C.; data curation, S.X.-F.A., Z.S.A.; writing-original draft preparation, S.X.-F.A.; writingreview and editing, W.Z., J.S., J.C., S.D.; visualization, S.X.-F.A.; supervision, W.Z., J.C.; project administration, W.Z.; funding acquisition, J.S. All authors have read and agreed to the published version of the manuscript.

Funding: This study was supported by NIH/National Institute of Environmental Health Sciences Grants Numbers R01ES008146, R01ES027078, and R01ES025750.

Institutional Review Board Statement: The study was conducted according to the guidelines of the Declaration of Helsinki, and approved by the Institutional Review Board (or Ethics Committee) of Purdue University (Protocol\# IACUC-1112000526 and date of approval on 17 May 2019).

Informed Consent Statement: Not applicable.

Data Availability Statement: The datasets generated during and/or analyzed during the current study are available from the corresponding author on reasonable request.

Acknowledgments: We appreciate Wendy Jiang for her technical support for this study.

Conflicts of Interest: The authors declare that they have no potential conflict of interest with respect to the research, authorship, and/or publication of this article.

\section{References}

1. Lorraine, G.; Christine, K.; Harry, J.M. Iron and copper in fetal development. Semin. Cell Dev. Biol. 2011, 22, 637-644. [CrossRef]

2. Turski, M.L.; Thiele, D.J. New roles for copper metabolism in cell proliferation, signaling, and disease. J. Biol. Chem. 2009, 284, 717-721. [CrossRef]

3. Uriu-Adams, J.; Scherr, R.; Lanoue, L.; Keen, C.L. Influence of copper on early development: Prenatal and postnatal considerations. Biofactors 2010, 36, 136-152. [CrossRef] [PubMed]

4. Zhang, T.; Xu, L.; Wu, J.J.; Wang, W.M.; Mei, J.; Ma, X.F.; Liu, J.X. Transcriptional responses and mechanisms of copper-induced dysfunctional locomotor behavior in zebrafish embryos. Toxicol. Sci. 2015, 148, 299-310. [CrossRef]

5. Joseph, R.P.; Bruce, B. Dietary copper deficiency alters protein levels of rat dopamine $\beta$-monooxygenase and tyrosine monooxygenase. Exp. Biol. Med. 2001, 226, 199-207. [CrossRef]

6. Scheiber, I.F.; Mercer, J.F.B.; Dringen, R. Metabolism and functions of copper in brain. Prog. Neurobiol. 2014, 116, 33-57. [CrossRef] [PubMed]

7. Skjorringe, T.; Moller, L.; Moos, T. Impairment of interrelated iron- and copper homeostatic mechanisms in brain contributes to the pathogenesis of neurodegenerative disorders. Front. Pharmacol. 2012, 3, 169. [CrossRef] [PubMed]

8. Takahashi, Y.; Kako, K.; Kashiwabara, S.; Takehara, A.; Inada, A.; Arai, H.; Nakada, K.; Kodama, H.; Hayashi, J.; Baba, T.; et al. Mammalian copper chaperone Cox17p has an essential role in activation of cytochrome c oxidase and embryonic development. Mol. Cell Biol. 2002, 22, 7614-7621. [CrossRef] [PubMed]

9. Danks, D.M. Disorders of Copper Transport. In The Metabolic and Molecular Bases of Inherited Disease; Scriver, C.L., Beaudet, A.L., Sly, W.S., Valle, D., Eds.; McGraw-Hill: New York, NY, USA, 1995; pp. 2211-2235.

10. Telianidis, J.; Hung, Y.H.; Materia, S.; Fontaine, S.L. Role of the P-Type ATPases, ATP7A and ATP7B in brain copper homeostasis. Front. Aging Neurosci. 2013, 5, 44. [CrossRef]

11. Gaggelli, E.; Kozlowski, H.; Valensin, D.; Valensin, G. Copper homeostasis and neurodegenerative disorders (Alzheimer's, prion, and Parkinson's diseases and amyotrophic lateral sclerosis). Chem. Rev. 2006, 106, 1995-2044. [CrossRef] [PubMed]

12. Greenough, M.A.; Camakaris, J.; Bush, A.I. Metal dyshomeostasis and oxidative stress in Alzheimer's disease. Neurochem. Int. 2013, 62, 540-555. [CrossRef] [PubMed]

13. Davies, K.M.; Mercer, J.F.B.; Chen, N.; Double, K.L. Copper dyshomeostasis in Parkinson's disease: Implications for pathogenesis and indications for novel therapeutics. Clin. Sci. 2016, 130, 565-574. [CrossRef] [PubMed]

14. Liddell, J.R.; Bush, A.I.; White, A.R. Copper in brain and neurodegeneration. In Encyclopedia of Inorganic and Bioinorganic Chemistry; Cuotta, V., Scott, R.A., Eds.; Wiley: Hoboken, NJ, USA, 2013. [CrossRef]

15. Rivera-Mancia, S.; Perez-Neri, I.; Rios, C.; Tristan-Lopez, L.; Rivera-Espinosa, L.; Montes, S. The transition metals copper and iron in neurodegenerative diseases. Chem. Biol. Interact. 2010, 186, 184-199. [CrossRef] 
16. Jiang, Y.M.; Zheng, W.; Long, L.L.; Zhao, W.J.; Li, X.R.; Mo, X.A.; Lu, J.P.; Fu, X.; Li, W.M.; Liu, S.T.; et al. Brain magnetic resonance imaging and manganese concentrations in red blood cells of smelting workers: Search for biomarkers of manganese exposure. Neurotoxicology 2007, 28, 126-135. [CrossRef]

17. Li, G.J.; Zhang, L.L.; Lu, L.; Wu, P.; Zheng, W. Occupational exposure to welding fume among welders: Alterations of manganese, iron, zinc, copper, and lead in body fluids and the oxidative stress status. J. Occup. Environ. Med. 2004, 46, 241-248. [CrossRef] [PubMed]

18. Wang, D.X.; Du, X.Q.; Zheng, W. Alteration of saliva and serum concentrations of manganese, copper, zinc, cadmium and lead among career welders. Toxicol. Lett. 2008, 176, 40-47. [CrossRef]

19. Fu, S.; Jiang, W.; Zheng, W. Age-dependent increase of brain copper levels and expressions of copper regulatory proteins in the subventricular zone and choroid plexus. Front. Mol. Neurosci. 2015, 8, 22. [CrossRef]

20. Guilarte, T.R.; McGlothan, J.L.; Degaonkar, M.; Chen, M.K.; Barker, P.B.; Syversen, T.; Schneider, J.S. Evidence for cortical dysfunction and widespread manganese accumulation in the nonhuman primate brain following chronic manganese exposure: A 1H-MRS and MRI study. Toxicol. Sci. 2006, 94, 351-358. [CrossRef]

21. Lai, J.C.; Minski, M.J.; Chan, A.W.; Leung, T.K.; Lim, L. Manganese mineral interactions in brain. NeuroToxicology 1999, 20, 433-444.

22. Zheng, W.; Jiang, Y.M.; Zhang, Y.S.; Jiang, W.; Wang, X.Q.; Cowan, D.M. Chelation therapy of manganese intoxication with para-aminosalicylic acid (PAS) in Sprague-Dawley rats. Neurotoxicology 2009, 30, 240-248. [CrossRef]

23. Pushkar, Y.; Robison, G.A.; Sullivan, G.; Fu, X.; Kohne, M.; Jiang, W.; Rohr, S.; Lai, B.; Marcus, M.A.; Zakharova, T.; et al. Aging results in copper accumulations in subventricular astrocytes. Aging Cell 2013, 12, 823-832. [CrossRef] [PubMed]

24. Fu, S.; O'Neal, S.; Hong, L.; Jiang, W.; Zheng, W. Elevated adult neurogenesis in brain subventricular zone following in vivo manganese exposure: Roles of copper and DMT1. Toxicol. Sci. 2015, 143, 482-498. [CrossRef]

25. El Meskini, R.; Crabtree, K.L.; Cline, L.B.; Mains, R.E.; Eipper, B.A.; Ronnett, G.V. ATP7A (Menkes protein) functions in axonal targeting and synaptogenesis. Mol. Cell Neurosci. 2007, 34, 409-421. [CrossRef] [PubMed]

26. Haremaki, T.; Fraser, S.T.; Kuo, Y.M.; Baron, M.H.; Weinstein, D.C. Vertebrate Ctr1 coordinates morphogenesis and progenitor cell fate and regulates embryonic stem cell differentiation. Proc. Natl. Acad. Sci. USA 2007, 104, 12029-12034. [CrossRef]

27. Niciu, M.J.; Ma, X.M.; El Meskini, R.; Pachter, J.S.; Mains, R.E.; Eipper, B.A. Altered ATP7A expression and other compensatory responses in a murine model of Menkes disease. Neurobiol. Dis. 2007, 27, 278-291. [CrossRef]

28. Lledo, P.M.; Alonso, M.; Grubb, M.S. Adult neurogenesis and functional plasticity in neuronal circuits. Nat. Rev. Neurosci. 2006, 7, 179-193. [CrossRef]

29. Maki, T.; Liang, A.C.; Miyamoto, N.; Lo, E.H.; Arai, K. Mechanisms of oligodendrocyte regeneration from ventricularsubventricular zone-derived progenitor cells in white matter diseases. Front. Cell Neurosci. 2013, 7, 275. [CrossRef] [PubMed]

30. Lois, C.; García-Verdugo, J.M.; Alvarez-Buylla, A. Chain migration of neuronal precursors. Science 1996, 271, 978-981. [CrossRef]

31. Martino, G.; Pluchino, S. The therapeutic potential of neural stem cells. Nat. Rev. Neurosci. 2006, 7, 395-406. [CrossRef] [PubMed]

32. Berendse, H.; Booij, J.; Francot, C.M.; Bergmans, P.L.; Hijman, R.; Stoof, J.C.; Wolters, J.C. Subclinical dopaminergic dysfunction in asymptomatic Parkinson's disease patients' relatives with a decreased sense of smell. Ann. Neurol. 2001, 50, 34-41. [CrossRef]

33. Langston, J. The Parkinson's complex: Parkinsonism is just the tip of the iceberg. Ann. Neurol. 2006, 59, 591-596. [CrossRef] [PubMed]

34. Montgomery, E.; Baker, K.; Lyons, K.; Koller, W. Abnormal performance on the PD test battery by asymptomatic first-degree relatives. Neurology 1999, 52, 757-762. [CrossRef] [PubMed]

35. Ponsen, M.; Stoffers, D.; Booij, J.; van Eck-Smit, B.; Wolters, E.; Berendse, H. Idiopathic hyposmia as a preclinical sign of Parkinson's disease. Ann. Neurol. 2004, 56, 173-181. [CrossRef]

36. Ross, G.W.; Petrovitch, H.; Abbott, R.D.; Tanner, C.M.; Popper, J.; Masaki, K.; Launer, L.; White, L.R. Association of olfactory dysfunction with risk for future Parkinson's disease. Ann. Neurol. 2008, 3, 167-173. [CrossRef]

37. Chen LWang, X.; Doty, R.L.; Cao, S.; Yang, J.; Sun, F.; Yan, X. Olfactory impairment in Wilson's disease. Brain Behav. 2021, 11, e02022. [CrossRef]

38. Mueller, A.; Reuner, U.; Landis, B.; Kitzler, H.; Reichmann, H.; Hummel, T. Extrapyramidal symptoms in Wilson's disease are associated with olfactory dysfunction. Mov. Disord. 2006, 21, 1311-1316. [CrossRef]

39. Zheng, W.; Monnot, A.D. Regulation of brain iron and copper homeostasis by brain barrier systems: Implication in neurodegenerative diseases. Pharmacol. Ther. 2012, 133, 177-188. [CrossRef] [PubMed]

40. Zheng, G.; Chen, J.Y.; Zheng, W. Relative contribution of CTR1 and DMT1 in copper transport by the blood-CSF barrier: Implication in manganese-induced neurotoxicity. Toxicol. Appl. Pharmacol. 2012, 260, 285-293. [CrossRef]

41. Fu, X.; Zhang, Y.S.; Jiang, W.; Monnot, A.D.; Bates, C.A.; Zheng, W. Regulation of copper transport crossing brain barrier systems by Cu-ATPases: Effect of manganese exposure. Toxicol. Sci. 2014, 139, 432-451. [CrossRef] [PubMed]

42. Hidalgo, J.; Aschner, M.; Zatta, P.; Vasak, M. Roles of the metallothionein family of proteins in the central nervous system. Brain Res. Bull. 2001, 55, 133-145. [CrossRef]

43. Kuo, Y.M.; Gybina, A.A.; Pyatskowit, J.W.; Gitschier, J.; Prohaska, J.R. Copper transporter protein (Ctr1) levels in mice are tissue specific and dependent on copper status. J. Nutr. 2006, 136, 21-26. [CrossRef]

44. Gybina, A.A.; Tkac, I.; Prohaska, J.R. Copper deficiency alters the neurochemical profile of developing rat brain. Nutr. Neurosci. 2009, 12, 114-122. [CrossRef] 
45. Liao, Z.; Medeiros, D.M.; McCune, S.A.; Prochaska, L.J. Cardiac levels of fibronectin, laminin, isomyosins, and cytochrome c oxidase of weanling rats are more vulnerable to copper deficiency than those of postweanling rats. J. Nutr. Biochem. 1995, 6, 385-391. [CrossRef]

46. Mizuno, S.; Yasuo, M.; Bogaard, H.J.; Kraskauskas, D.; Alhussaini, A.; Gomez-Arroyo, J.; Farkas, D.; Farkas, L.; Voelkel, N.F. Copper deficiency induced emphysema is associated with focal adhesion kinase inactivation. PLoS ONE 2012, 7, e30678. [CrossRef] [PubMed]

47. Nelson, K.T.; Proshaska, J.R. Copper deficiency in rodents alters dopamine beta-mono-oxygenase activity, mRNA and protein level. Br. J. Nutr. 2009, 102, 18-28. [CrossRef] [PubMed]

48. Owen, C.A., Jr.; Hazelrig, J.B. Copper deficiency and copper toxicity in the rat. Am. J. Physiol. 1968, 215, 334-338. [CrossRef]

49. Pal, A.; Vasishta, R.K.; Prasad, R. Hepatic and hippocampus iron status is not altered in response to increased serum ceruloplasmin and serum "free" copper in Wistar rat model for non-Wilsonian brain copper toxicosis. Biol. Trace Elem. Res. 2013, 154, 403-411. [CrossRef] [PubMed]

50. Pal, A.; Badyal, R.K.; Vasishta, R.K.; Attri, S.V.; Thapa, B.R.; Prasad, R. Biochemical, histological, and memory impairment effects of chronic copper toxicity: A model for non-Wilsonian brain copper toxicosis in Wistar rat. Biol. Trace Elem. Res. 2013, 153, 257-268. [CrossRef]

51. Pal, A.; Prasad, R. Regional distribution of copper, zinc and iron in brain of Wistar rat model for non-Wilsonian brain copper toxicosis. Indian J. Clin. Biochem. 2016, 31, 93-98. [CrossRef] [PubMed]

52. Song, M.; Zhou, Z.; Chen, T.; Zhang, J.; McCalin, C.J. Copper deficiency exacerbates bile duct ligation-induced liver injury and fibrosis in rats. J. Pharmacol. Exp. Ther. 2011, 339, 298-306. [CrossRef]

53. Kim, J.; Choi, Y.; Ahn, M.; Jung, K.; Shin, T. Olfactory dysfunction in autoimmune central nervous system neuroinflammation. Mol. Neurobiol. 2018, 55, 8499-8508. [CrossRef]

54. Lehmkuhl, A.M.; Dirr, E.R.; Fleming, S.M. Olfactory assays for mouse models of neurodegenerative disease. J. Vis. Exp. 2014, 25, e51804. [CrossRef]

55. Yang, M.; Crawley, J.N. Simple behavioral assessment of mouse olfaction. Curr. Protoc. Neurosci. 2009, 8, 24. [CrossRef] [PubMed]

56. Choi, B.S.; Zheng, W. Copper transport to the brain by the blood-brain barrier and blood-CSF barrier. Brain Res. 2009, 1248, 14-21. [CrossRef] [PubMed]

57. Coggeshall, R.E.; Lekan, H.A. Methods for determining numbers of cells and synpses: A case for more uniform standards of review. J. Comp. Neurol. 1996, 364, 6-15. [CrossRef]

58. Adamson, S.F.; Shen, S.; Jiang, W.; Lai, V.; Wang, X.; Shannahan, J.H.; Cannon, J.; Chen, J.H.; Zheng, W. Subchronic manganese exposure impairs neurogenesis in the adult rat hippocampus. Toxicol. Sci. 2018, 163, 592-608. [CrossRef] [PubMed]

59. O'Neal, S.L.; Hong, L.; Fu, S.; Jiang, W.; Jones, A.; Nie, L.H.; Zheng, W. Manganese accumulation in bone following chronic exposure in rats: Steady-state concentration and half-life in bone. Toxicol. Lett. 2014, 229, 93-100. [CrossRef]

60. Agim, Z.S.; Cannon, J.R. Alteration in the nigrostriatal dopamine system after acute systemic PhIP exposure. Toxicol. Lett. 2018, 287, 31-41. [CrossRef]

61. Fu, S.; Jiang, W.; Gao, X.; Zeng, A.; Cholger, D.; Cannon, J.; Chen, J.; Zheng, W. Aberrant adult neurogenesis in the subventricular zone-rostral migratory stream-olfactory bulb system following subchronic manganese exposure. Toxicol. Sci. 2016, 150, 347-368. [CrossRef]

62. Nagayama, S.; Homma, R.; Imamura, F. Neuronal organization of olfactory bulb circuits. Front. Neural Circuits 2014, 8, 98. [CrossRef]

63. Alvarez-Buylla, A.; Lim, D.A. For the long run: Maintaining germinal niches in the adult brain. Neuron 2004, 41, 683-686. [CrossRef]

64. Ghashghaei, H.T.; Lai, C.; Anton, E.S. Neuronal migration in the adult brain: Are we there yet? Nat. Rev. Neurosci. 2007, 8, 141-151. [CrossRef] [PubMed]

65. Lie, D.C.; Song, H.; Colamarino, S.A.; Ming, G.L.; Gage, F.H. Neurogenesis in the adult brain: New strategies for central nervous system diseases. Ann. Rev. Pharmacol. Toxicol. 2004, 44, 399-421. [CrossRef]

66. Kawano, T.; Margolis, F.L. Transsynaptic regulation of olfactory bulb catecholamines in mice and rats. J. Neurochem. 1982, 39, 342-348. [CrossRef]

67. Huisman, E.; Uylings, H.B.; Hoogland, P.V. A 100\% increase of dopaminergic cells in the olfactory bulb may explain hyposmia in Parkinson's disease. Mov. Disord. 2004, 19, 687-692. [CrossRef] [PubMed]

68. Marin, C.; Vilas, D.; Langdon, C.; Alobid, I.; López-Chacón, M.; Haehner, A.; Hummel, T.; Mullol, J. Olfactory dysfunction in neurodegenerative disease. Curr. Allergy Asthma Rep. 2018, 18, 42. [CrossRef]

69. Ubeda-Bañon, I.; Saiz-Sanchez, D.; Flores-Cuadrado, A.; Rioja-Corroto, E.; Gonzalez-Rodriguez, M.; Villar-Conde, S.; AstilleroLopez, V.; Cabello-de la Rosa, J.P.; Gallardo-Alcañiz, M.J.; Vaamonde-Gamo, J.; et al. The human olfactory system in two proteinopathies: Alzheimer's and Parkinson's diseases. Transl. Neurodegener. 2020, 9, 22. [CrossRef] [PubMed]

70. Fullard, M.E.; Morley, J.F.; Duda, J.E. Olfactory dysfunction as an early biomarker in Parkinson's disease. Neurosci. Bull. 2017, 33, 515-525. [CrossRef]

71. Baldwin, D.H.; Sandahl, J.F.; Labenia, J.S.; Scholz, N.L. Sublethal effects of copper on coho salmon: Impacts on nonoverlapping receptor pathways in the peripheral olfactory nervous system. Environ. Toxicol. Chem. 2003, 22, 2266-2274. [CrossRef] 
72. Julliard, A.K.; Saucier, D.; Astic, L. Time-course of apoptosis in the olfactory epithelium of rainbow trout exposed to low copper level. Tissue Cell 1996, 28, 367-377. [CrossRef]

73. Mclntyre, J.K.; Baldwin, D.H.; Beauchamp, D.A.; Scholz, N.L. Low-level copper exposures increase visibility and vulnerability of juvenile coho salmon to cutthroat trout predators. Ecol. Appl. 2012, 22, 1460-1471. [CrossRef] [PubMed]

74. Dew, W.A.; Wood, C.M.; Pyle, G.G. Effects of continuous copper exposure and calcium on the olfactory response of fathead minnows. Environ. Sci. Technol. 2012, 46, 9019-9026. [CrossRef] [PubMed]

75. Donaldson, J.; Pierre, T.S.; Minnich, J.L.; Barbeau, A. Determination of $\mathrm{Na}+, \mathrm{K}+, \mathrm{Mg} 2+, \mathrm{Cu} 2+$, $\mathrm{Zn} 2+$, and $\mathrm{Mn} 2+$ in rat brain regions. Can. J. Biochem. 1973, 51, 87-92. [CrossRef] [PubMed]

76. Ono, S.; Cherian, M.G. Regional distribution of metallothionein, zinc, and copper in the brain of different strains of rats. Biol Trace Elem. Res. 1999, 69, 151-159. [CrossRef] [PubMed]

77. Friedman, B.; Price, J.L. Fiber systems in the olfactory bulb and cortex: A study in adult and developing rats, using the timm method with the light and electron microscope. J. Comp. Neurol. 1984, 223, 88-109. [CrossRef]

78. Jo, S.M.; Won, M.H.; Cole, T.B.; Jensen, M.S.; Palmiter, R.D.; Danscher, G. Zinc-enriched (ZEN) terminals in mouse olfactory bulb. Brain Res. 2000, 26, 227-236. [CrossRef]

79. Pérez-Clausell, J.; Danscher, G. Intravesicular localization of zinc in rat telencephalic boutons. A histochemical study. Brain Res. 1985, 24, 91-98. [CrossRef] [PubMed]

80. Delgado, R.; Vergara, C.; Wolff, D. Divalent cations as modulators of neuronal excitability: Emphasis on copper and zinc. Biol. Res. 2006, 39, 173-182. [CrossRef]

81. Horning, M.S.; Trombley, P.Q. Zinc and copper influence excitability of rat olfactory bulb neurons by multiple mechanisms. J. Neurophysiol. 2001, 86, 1652-1660. [CrossRef] [PubMed]

82. Trombley, P.Q.; Horning, M.S.; Blakemore, L.J. Interactions between carnosine and zinc and copper: Implications for neuromodulation and neuroprotection. Biochemistry 2000, 65, 807-816.

83. Trombley, P.Q.; Shepherd, G.M. Differential modulation by zinc and copper of amino acid receptors from rat olfactory bulb neurons. J. Neurophysiol. 1996, 76, 2536-2546. [CrossRef] [PubMed]

84. Ma, E.Y.; Heffern, K.; Cheresh, J.; Gallagher, E.P. Differential copper-induced death and regeneration of olfactory sensory neuron populations and neurobehavioral function in larval zebrafish. Neurotoxicology 2018, 59, 141-151. [CrossRef] [PubMed]

85. Zeng, H.; Saari, J.T. Increased type I collagen content and DNA binding activity of a single-stranded, cytosine-rich sequence in the high-salt buffer protein extract of the copper-deficient rat heart. J. Nutr. Biochem. 2004, 15, 694-699. [CrossRef] [PubMed]

86. Prohaska, J.R.; Bailey, W.R. Regional specificity in alterations of rat brain copper and catecholamines following perinatal copper deficiency. J. Neurochem. 1994, 63, 1551-1557. [CrossRef]

87. D'Ambrosi, N.; Rossi, L. Copper at synapse: Release, binding and modulating of neurotransmission. Neurochem. Int. 2015, 90, 36-45. [CrossRef]

88. Gaier, E.D.; Eipper, B.A.; Mains, R.E. Copper signaling in the mammalian nervous system: Synaptic effects. J. Neurosci. Res. 2013, 91, 2-19. [CrossRef]

89. Becker, J.S.; Zoriy, M.V.; Pickhardt, C.; Palomero-Gallagher, N.; Zilles, K. Imaging of copper, zinc, and other elements in thin section of human brain samples (hippocampus) by laser ablation inductively coupled plasma mass spectrometry. Anal. Chem. 2005, 77, 3208-3216. [CrossRef]

90. Davies, K.M.; Hare, D.J.; Cottam, V.; Chen, N.; Hilgers, L.; Halliday, G.; Mercer, J.F.; Double, K.L. Localization of copper and copper transporters in the human brain. Metallomics 2013, 5, 43-51. [CrossRef]

91. Dobrowolska, J.; Dehnhardt, M.; Matusch, A.; Zoriy, M.; Palomero-Gallagher, N.; Koscielniak, P.; Zilles, K.; Becker, J.S. Quantitative imaging of zinc, copper and lead in three distinct regions of the human brain by laser ablation inductively coupled plasma mass spectrometry. Talanta 2008, 74, 717-723. [CrossRef] [PubMed]

92. Lech, T.; Sadlik, J.K. Copper concentration in body tissues and fluids in normal subjects of southern Poland. Biol. Trace Elem. Res. 2007, 118, 10-15. [CrossRef] [PubMed]

93. Ramos, P.; Santos, A.; Pinto, N.R.; Mendes, R.; Magalhães, T.; Almeida, A. Anatomical region differences and age-related changes in copper, zinc, and manganese levels in the human brain. Biol. Trace Elem. Res. 2014, 161, 190-201. [CrossRef]

94. Jackson, B.; Harper, S.; Smith, L.; Flinn, J. Elemental mapping and quantitative analysis of $\mathrm{Cu}, \mathrm{Zn}$, and Fe in rat brain sections by laser ablation ICP-MS. Anal. Bioanal. Chem. 2006, 384, 951-957. [CrossRef] [PubMed]

95. Olusola, A.O.; Obodozie, O.O.; Nssien, M.; Adaramoye, A.; Adesanoye, O.; Odama, L.E.; Emerole, G.O. Concentrations of copper, iron, and zinc in the major organs of the wistar albino and wild black rats: A comparative study. Biol. Trace Elem. Res. 2004, 98, 265-274. [CrossRef]

96. Waggoner, D.J.; Drisaldi, B.; Bartnikas, T.B.; Casareno, R.L.; Prohaska, J.R.; Gitlin, J.D.; Harris, D.A. Brain copper content and cuproenzyme activity do not vary with prion protein expression level. J. Biol. Chem. 2000, 275, 7455-7458. [CrossRef]

97. Palm, R.; Wahlström, G.; Hallmans, G. Age related changes in weight and the concentrations of zinc and copper in the brain of the adult rat. Lab. Anim. 1990, 24, 240-245. [CrossRef]

98. Serpa, R.F.; de Jesus, E.F.; Anjos, M.J.; de Oliverira, L.F.; Marins, L.A.; do Carmo, M.G.; Correa, J.D.; Rocha, M.S.; Lopes, R.T.; Martinez, A.M. Topographic trace-elemental analysis in the brain of Wistar rats by X-ray microfluorescence with synchrontron radiation. Anal. Sci. 2008, 24, 839-842. [CrossRef] 
99. Tarohda, T.; Yamamoto, M.; Amamo, R. Regional distribution of manganese, iron, copper, and zine in the rat brain during development. Anal. Bioanal. Chem. 2004, 380, 617-624. [CrossRef] [PubMed]

100. Wang, L.M.; Becker, J.S.; Wu, Q.; Oliverira, M.F.; Bozza, F.A.; Schwager, A.L.; Hoffman, J.M.; Morton, K.A. Bioimaging of copper alterations in the aging mouse brain by autoradiography, laser ablation inductively coupled plasma mass spectrometry and immunohistochemistry. Metallomics 2010, 2, 348-353. [CrossRef] [PubMed]

101. Goldberg, W.J.; Allen, N. Determination of $\mathrm{Cu}, \mathrm{Mn}, \mathrm{Fe}$, and $\mathrm{Ca}$ in six regions of normal human brain, by atomic absorption spectroscopy. Clin. Chem. 1981, 27, 562-564. [CrossRef]

102. Propescu, B.F.; George, M.J.; Bergmann, U.; Garachtchenko, A.V.; Kelly, M.E.; McCrea, R.P.; Luning, K.; Devon, R.M.; George, G.N.; Hanson, A.D.; et al. Mapping metals in Parkinson's and normal brain using rapid-scanning x-ray fluorescence. Phys. Med. Biol. 2009, 54, 651-663. [CrossRef] [PubMed]

103. Warren, P.J.; Earl, C.J.; Thompson, R.H. The distribution of copper in human brain. Brain 1960, 83, 709-717. [CrossRef]

104. Sullivan, B.; Robison, G.; Osborn, J.; Kay, M.; Thompson, P.; Davis, K.; Zakharova, T.; Antipova, O.; Pushkar, Y. On the nature of the $\mathrm{Cu}$-rich aggregates in brain astrocytes. Redox Biol. 2017, 11, 231-239. [CrossRef] [PubMed]

105. Sullivan, B.; Robison, G.; Pushkar, Y.; Young, J.K.; Manaye, K.F. Copper accumulation in rodent brain astrocytes: A species difference. J. Trace Elem. Med. Biol. 2017, 39, 6-13. [CrossRef] [PubMed]

106. Russell, Y.; Evans, P.; Dodd, G.H. Characterization of the total lipid and fatty acid composition of rat olfactory mucosa. J. Lipid Res. 1989, 30, 877-884. [CrossRef]

107. Sebio, R.M.; Ferrarotti, N.; Lairion, F.; Magriñá, C.S.; Fuda, J.; Torti, H.; Boveris, A.; Repetto, M.G. Brain oxidative stress in rat with chronic iron or copper overload. J. Inorg. Biochem. 2019, 199, 110799. [CrossRef] 